\title{
Significance of selenium supplementation in root- shoot reactions under manganese stress in wheat seedlings - biochemical and cytological studies
}

\author{
Apolonia Sieprawska (D) Magdalena Skórka • \\ Elżbieta Bednarska-Kozakiewicz • Katarzyna Niedojadło • \\ Agnieszka Janiak · Anna Telk • Maria Filek
}

Received: 6 June 2021 / Accepted: 23 August 2021 / Published online: 8 September 2021

(C) The Author(s) 2021

\begin{abstract}
Purpose Agronomic practices are one of the reasons for the increasing accumulation of elements in the soil, including manganese (Mn). Our previous studies have shown that selenium (Se) ions can reduce the toxic actions of metal stress. Those, we studied the effects of Mn-treated as a stressor and $\mathrm{Se}-$ as a potential defense in plants.

Methods $\mathrm{Mn}$ ions $(10 \mathrm{mM})$ or/and Se $(15 \mu \mathrm{M})$ were added into hydroponic nutrients of two wheat cultivares. The evaluation of the stress-generating and protective actions were analyzed by biochemical
\end{abstract}

Responsible Editor: Juan Barcelo

Supplementary Information The online version contains supplementary material available at https://doi. org/10.1007/s11104-021-05138-x.

A. Sieprawska $(\bowtie) \cdot$ M. Skórka $\cdot$ M. Filek

Department of Biochemistry, Biophysics

and Biotechnology, Institute of Biology, Pedagogical

University, Podchorążych 2, 30-084 Krakow, Poland

e-mail: apolonia.sieprawska@up.krakow.pl

M. Skórka

e-mail: magdalena.skorka1@ student.up.krakow.pl

M. Filek

e-mail: maria.filek@up.krakow.pl

E. Bednarska-Kozakiewicz · K. Niedojadło

Faculty of Biological and Veterinary Sciences, Institute of Biology, Nicolaus Copernicus University in Toruń, Lwowska 1, 87-100 Toruń, Poland

e-mail: ebedn@umk.pl methods and microscopic observations in leaves and roots. Moreover the level of DNA methylation for these tissues was determined.

Results Mn application caused an increase of lipid peroxidation and hydrogen peroxide content in both leaves and roots and was accompanied with a greater absorption of this element by the roots. For other elements $(\mathrm{K}, \mathrm{Fe}, \mathrm{S}, \mathrm{P})$, with the exception of $\mathrm{Ca}$, the reduced their uptake was registered, especially in roots. For roots, Mn stimulated greater, microscopically observed, desorganization in cell structure as compared to leaves, which was accompanied by a quantitative increase in 5-methylcytosine (5-metC) in root meristem. Se application diminished the effects of Mn-stress.

\section{K. Niedojadło \\ e-mail: karask@umk.pl}

\section{A. Janiak}

Institute of Biology, Biotechnology and Environmental Protection, Faculty of Natural Sciences, University of Silesia in Katowice, Jagiellońska 28, 40-032 Katowice, Poland

e-mail: agnieszka.janiak@us.edu.pl

A. Telk

Department of Analytical Chemistry, Faculty

of Chemistry, Jagiellonian University, Gronostajowa 2,

30-387 Krakow, Poland

e-mail: anna.telk@uj.edu.pl 
Conclusions These studies is the first in which indicated that global 5-metC level in roots enhancing from dividing meristematic cells to elongating cells of the axial cylinder and cortex. It was suggested that the rise in Ca level can lead to modification of root cells differentiations what may be one of the steps in defense mechanisms.

Keywords Manganese stress $\cdot$ Selenium $\cdot$ Wheat seedlings $\cdot$ DNA methylation

\section{Introduction}

Understanding the mechanism of action of biotic and abiotic stresses in plants still requires extensive research in order to unveil biochemical properties of cells that lead to minimization of toxic effects. The intensity of a stressor action, as well as specific response of species and even cultivars to the stress, are some of the reasons that make a detailed description of stages in stress adaptation process difficult. In most research papers overproduction of reactive oxygen species (ROS), is accepted as an important step in the mechanism the stress action (Nita and Grzybowski 2016). One of those ROS are the superoxide anion radical and $\mathrm{H}_{2} \mathrm{O}_{2}$ responsible, among others, for inducing changes in the structure of cell membranes by increasing saturation of the fatty acids (recorded as an increase in MDA content) (Ayala et al. 2014). Thus, MDA level fluctuation is demonstrated as one of the factors informing about the stress intensity. The modification of the lipid structure may disturb the activity of protein channels and transporters located in the membranes and affect ion transportation. Among the ions especially important for proper functioning of cells are the cations of calcium $(\mathrm{Ca})$, magnesium $(\mathrm{Mg})$, and potassium $(\mathrm{K})$, and the anions of sulfur (S) and phosphorus (P) (analyzed in mg concentrations), and also the cations of manganese $(\mathrm{Mn})$, zinc $(\mathrm{Zn})$, copper $(\mathrm{Cu})$, and iron $(\mathrm{Fe})$ (present in $\mu \mathrm{g}$ amounts). The role of $\mathrm{Ca}$ in plant cell homeostasis is particularly significant, as it mediates signals from the roots to the shoots in the process of adaptation to the environmental conditions and ROS overproduction (Sharma et al. 2017). Magnesium presence in activity centers of organic components is essential to stimulate many metabolic reactions that depend on protein synthesis, phosphorylation, photooxidation or enzyme activation (Cakmak and Yazici 2010). Similarly, $\mathrm{K}$ is involved in protein synthesis, enzyme activation and energy transfer, but also in osmoregulation and cation-anion balance, which were analyzed in aspects of biotic and abiotic stresses (Wang et al. 2013). Sulfur presence in amino acids of numerous enzymes increases plant tolerance to stress factors (Liang et al. 2016). The importance of $P$ is mainly considered in terms of its contribution to the structure of nucleic acids. This macronutrient stabilizes the membrane structures and mediates the activation of enzymes and carbohydrate metabolism (Razaq et al. 2017; Malhotra et al. 2018). Membrane proteins containing $\mathrm{S}$ and/or $\mathrm{P}$ may serve as transporters in the translocation of various ions from and to cells (Sasaki et al. 2012). Zinc, copper and iron serve as co-factors of many enzymes, including those participating in antioxidant protection (Andresen et al. 2018). Zinc participates in the regulation of gene expression shaping plant tolerance under stress and is involved in protein synthesis and carbohydrate metabolism (Hafeez et al. 2013). Iron is a fundamental element of biomolecules controlling the structure and function of chloroplasts and synthesis of chlorophyll (Rout and Sahoo 2011). Uptake of Fe into cells may be supported by $\mathrm{Cu}$ ions (Scheers 2013).

In recent years, high demand for Mn has significantly increased emission of this element into environment as an effect of intensification of $\mathrm{Mn}$ ore mining mainly for Mn alloy production, mainly in welding, coke ovens and to production of dry alkaline batteries. Additionally, many countries use Mncontaining agrochemicals such as fungicides and fertilizers (Röllin and Nogueira 2011). The ion is a cofactor and activator of numerous plant enzymes, such as oxalate oxidase, oxalate decarboxylase, enzymes involved in fatty acid synthesis, or synthesis of deoxyribonucleic acid and ribonucleic acid (Broadley et al. 2012; Schmidt and Husted 2019). Manganese presence is indispensable to maintain the redox balance and electron transfer reactions, which is why it plays a valid role in the regulation of excess ROS generation under stress (Maathius and Diatloff 2013). It is suggested that exogenous application of Mn ions limited damage to plant cells by improving antioxidant defense systems, ion homeostasis and diminishing toxic changes in lipid peroxidation, particularly under metal stress conditions (Rahmann et al. 2016; Sebastian and Prasad 2015; Gzyl-Malcher 
et al. 2019). However, too high concentration of Mn, above the optimal content in cells (specific for plant cultivars), may induce destructive effects in plant tissues by initiating stress reactions. Similarly, as under other stresses, ROS generation and activation of oxidation processes were demonstrated under Mn excess in plant cells (Führs et al. 2009, 2012; Li et al. 2010; Bradley et al. 2012). It was suggested that Mn toxicity is related to oxidation of $\mathrm{Mn}$ in the apoplast, and that Mn may serve as an oxidizer of lipids and proteins (Fecht-Christoffers et al. 2003). The ability of Mn to bind with sulfhydryl groups of proteins disturbs their chemical structure and in consequence disrupts the movement of basic components in plant cells Sharma and Dietz 2009). A decrease in the absorption of elements such as $\mathrm{Fe}, \mathrm{Mg}, \mathrm{Ca}$ and $\mathrm{P}$, characterized by a similar size of ions or the strength of ligand binding, was shown by Shi and Zhu (2008) and Millaleo et al. 2013). Chen et al. (2016) suggested that the modification of protein structure in the root system was the primary reason leading to growth inhibition in these organs. This suggests that the anatomical and chemical structure of the root system is essential to ensure proper uptake of substances from the soil and their transport to the leaves. Mn can be transferred via the plasma membranes of the root cells in a symplastic transport, or via the space between the root cells (apoplastic transport). Following absorption in the roots, Mn can be accumulated in the vacuole (as its main storage place) and/or the cell wall, and may also be transported to the leaves (via xylem). Rajpoot et al. (2021) showed that excessive Mn content (1-2 mM) in the growth media drastically changed the physicochemical conditions in the apical part of the roots.

One of the methods of protecting plants against stress induced by an excess of metals in the soil is the application of micro-amounts of selenium (Se) ions (Sieprawska et al. 2015; Mechora 2019). Such studies in the aspect of stress caused by Mn have not been conducted so far. Selenium is not required for plant physiological processes, but its presence is valued, especially in plants used as food products for humans and animals (Gupta and Gupta 2017). It is suggested that the mechanism of Se-based protection involves its blocking the uptake and transport of toxic substances (Koselski et al. 2019) and/or reducing the overproduction of ROS (Sieprawska et al. 2015; 2017). Another mechanism may be a Se-mediated modification of the methylation pattern disturbed by stress factors (Filek et al. 2008; Kleiber et al. 2018).

DNA methylation regulates many biological processes in plants, including their growth and development (Grafi et al. 2011; Chen and Zhou 2013; GuzyWróbelska et al. 2013). Changes in DNA methylation were also documented in plants exposed to biotic and abiotic stresses, however, its direction (demethylation and de-novo methylation) depended on factors such as plant species, developmental stage and stress intensity (Karan et al. 2012; Greco et al. 2012). DNA methylation may enhance crop adaptation to stress by serving as a protective system that maintains genome integrity, and as the main epigenetic mechanism that controls gene expression in cells (Tan 2010; Shan et al. 2013). Moreover, it was shown that stress resistant genotypes responded to stress with a decrease in the percentage of 5-methylcytosine (5-metC), in the DNA pattern, while sensitive ones with an increase in methylation level (Gayacharan 2013). However, other studies demonstrated the same pattern of changes in cytosine methylation irrespective of the level of stress tolerance of the genotypes (Karan et al. 2012). Therefore, further research in this area should be carried out to learn more about the mechanism of action of both stress and adaptation processes.

The presented study aims to demonstrate a possible protective effect of Se ions in wheat subjected to toxic concentration of $\mathrm{Mn}$ and to estimate the influence of $\mathrm{Mn}$ and Se treatment on DNA methylation. Two cultivars of wheat, differing in visible response to Mn (including the length of leaves and roots and alterations in the size and number of chlorotic spots), were selected for analysis. The aim of the research was achieved by: i) determining the amount of hydrogen peroxide and the degree of lipid peroxidation as indicators of stress intensity; ii) assessing changes in the content of macro- and microelements, including $\mathrm{Mn}$ and $\mathrm{Se}$, and modification of the membrane permeability as effect $\mathrm{Mn}$ and Se mediation in the transport of nutrients from the roots to the leaves; iii) measuring the content of soluble sugars and starch, important metabolites that may indicate disturbances in metabolic processes; iv) visualizing 5-metC content in the leaf and root cells; v) estimating the proportion of demethylated and methylated cytosine residues within CCGG sequence in DNA from the whole leaves and 
roots using Methylation-Sensitive Amplified Polymorphism (MSAP) method. Special attention was paid to the reactions occurring in the root system, the place of direct contact of $\mathrm{Mn} / \mathrm{Mn}+\mathrm{Se}$ with the plant tissues.

\section{Materials and methods}

\section{Plant material}

Grains of spring wheat (cv. 'Nimfa', cv. 'Alibi'), obtained from a Polish Plant Breeding Station in Strzelce, were sterilized with $80 \%$ ethanol and $10 \%$ perhydrol, and rinsed four times with distilled water. After sterilization the seeds were placed in Petri dishes and germinated for two days, at $20^{\circ} \mathrm{C}$ in darkness. Next, the seedlings were placed individually in the holes of polystyrene discs put on top of the vessels (10 1) filled with 50\% Hoagland medium (1:1; v:v) as a control, or supplemented with $10 \mathrm{mM} \mathrm{MnCl} 2(\mathrm{Mn}$ treatment), $10 \mathrm{mM} \mathrm{MnCl}{ }_{2}+15 \mu \mathrm{M} \mathrm{SeCl}_{2}(\mathrm{Mn}+\mathrm{Se}$ treatment), or $15 \mu \mathrm{M} \mathrm{SeCl}{ }_{2}(\mathrm{Se})$. The seedlings were grown in the hydroponic conditions with a relative humidity $45-50 \%$, light intensity $800 \mu \mathrm{mol}$ (photon) $\mathrm{m}^{-2} \mathrm{~s}^{-1}$ (SQS, Hansatech Ltd, Kings Lynn, United Kingdom), and $16 \mathrm{~h}$ photoperiod $\left(17 / 20{ }^{\circ} \mathrm{C}\right.$ night/ day) until the phase of the third leaf (about 12 days). Then the plants were collected, shoots were separated from roots, tissues were weighed and frozen in liquid nitrogen for biochemical and MSAP analysis. Microscopic analyzes were carried out in fresh leaves and roots.

\section{Determination of hydrogen peroxide}

One gram of fresh weight leaves or roots was homogenized with $2 \mathrm{ml}$ of a solution containing $0.25 \mathrm{ml}$ trichloroacetic acid (TCA) $(0.1 \% \quad(w: v)$ (Sergiev et al. 1997). The homogenate was centrifuged (MPW 251R) at $12,000 \times \mathrm{g}$ for $15 \mathrm{~min}$ at $4^{\circ} \mathrm{C}$. Then $0.5 \mathrm{ml}$ of the supernatant was taken and mixed with $0.5 \mathrm{ml}$ $\mathrm{KI}(1 \mathrm{M})$ and $0.25 \mathrm{ml}$ potassium phosphate buffer $(10 \mathrm{mM}, \mathrm{pH} 7.2)$ at $4^{\circ} \mathrm{C}$. The quantitative determination was performed based on calibration curves for $\mathrm{H}_{2} \mathrm{O}_{2}\left(0.0-1.0 \mu \mathrm{mol} \cdot \mathrm{g}^{-1}\right)$ prepared in $0.1 \% \mathrm{TCA}$ at $\lambda=395 \mathrm{~nm}$.
Determination of soluble sugars and starch

For analyses of soluble sugars, a method described by Janeczko et al. (2010) with same modifications was used. About $1 \mathrm{~g}$ of fresh weight leaves were homogenized with $80 \%$ (v:v) ethanol and the extract was centrifuged at $5,000 \times \mathrm{g}$ for $10 \mathrm{~min}$, at $4{ }^{\circ} \mathrm{C}$. Then, the supernatant was heated at $95{ }^{\circ} \mathrm{C}$ with anthrone $(0.2 \mathrm{~g}$ anthrone in $1000 \mathrm{ml} 72 \% \mathrm{H}_{2} \mathrm{SO}_{4}$ ) for $10 \mathrm{~min}$, and fast cooled to $20{ }^{\circ} \mathrm{C}$. Spectrophotometric measurements (Thermo Scientific Evolution 201/220 UV-Visible) at $\lambda=625 \mathrm{~nm}$ allowed us to determine the content of carbohydrates. For quantitative calculations, a curve with glucose $\left(1 \mathrm{mg} \cdot \mathrm{ml}^{-1}\right)$ as a standard was prepared.

Starch content was detected by the combined methods of Huber and Israel (1982) and Janeczko et al. (2010), in leaf samples $(1 \mathrm{~g})$ homogenized with $0.2 \mathrm{M} \mathrm{KOH}$. After heating for $30 \mathrm{~min}$, the samples were cooled and $1 \mathrm{M}$ acetic acid was added to neutralize the mixtures. Starch depolymerization into glucose was carried out in a medium with 0.5 unit of $\alpha$-amylase (EC 3211) for $15 \mathrm{~h}$ at $50{ }^{\circ} \mathrm{C}$. After centrifuging at $6,000 \times \mathrm{g}$ for $5 \mathrm{~min}$, glucose content was determined by the anthrone method, as described above.

Malonedialdehyde (MDA) analysis

One gram of fresh weight leaves and roots were homogenized in $0.5 \%(\mathrm{w} / \mathrm{v})$ TCA (trichloroacetic acid) in a cold room according to Dhindsa et al. (1981) and Tobiasz et al. (2014). After homogenization, the samples were centrifuged at $5000 \times \mathrm{g}$ for $20 \mathrm{~min}$, at $4{ }^{\circ} \mathrm{C}$ (MPW-351R). Then, $0.25 \%$ (w/v) TBA (thiobarbituric acid) in $10 \%(\mathrm{w} / \mathrm{v})$ TCA was added into the supernatant and the mixture was heated at $95{ }^{\circ} \mathrm{C}$ for $30 \mathrm{~min}$, quickly cooled on ice, and again centrifuged at $5,000 \times \mathrm{g}$ for $20 \mathrm{~min}$. Absorbance of the supernatant samples was measured at $\lambda=532 \mathrm{~nm}$ and $\lambda=600 \mathrm{~nm}$ using a Thermo Scientific Evolution 201/220 UV-Visible spectrophotometer.

\section{Macro- and micronutrient analysis}

Portions $(1.2 \mathrm{~g})$ of lyophilized plant material were weighed (with an accuracy of $10^{-5} \mathrm{~g}$ ) and mineralized with $6 \mathrm{ml}$ of concentrated nitric acid. Macronutrient content was detected by an inductively coupled plasma optic emission spectrometer ICP OES Optima 
2100 (Perkin Elmer) at the following wavelengths: Mn $259.372 \mathrm{~nm}, \mathrm{Mg} 285.213 \mathrm{~nm}$, Fe $238.204 \mathrm{~nm}$, Ca $317.933 \mathrm{~nm}, \mathrm{~S} 181.975 \mathrm{~nm}, \mathrm{P} 213.617 \mathrm{~nm}$ in axial plasma observation mode; K $766.490 \mathrm{~nm}$ in radial observation mode, and with high argon flow through the monochromator system. Micronutrient content determination was based on Cu63, Zn68 and Fe57 isotopes as standards and inductively coupled plasma mass spectrometry (ICPMS; Elan DRC-e, Perkin Elmer, Shelton, USA) (Tobiasz et al. 2014).

Microscopic observations and determination of 5-metC localization (5-metC)

The samples dissected from the leaves and roots were fixed with 4\% paraformaldehyde (Polysciences) and $0.25 \%$ glutaraldehyde (Sigma) in phosphate-buffered saline (PBS), $\mathrm{pH} \mathrm{7.2,} \mathrm{for} 24 \mathrm{~h}$ at $4{ }^{\circ} \mathrm{C}$ and prepared for embedding in BMM resin (butyl methacrylate, methyl methacrylate, $0.5 \%$ benzoyl ethyl ether (Sigma) with $10 \mathrm{mM}$ DDT (Thermo Fisher Scientific)) according to Niedojadło et al. (2015). The samples were cut on Leica UCT ultramicrotome into serial semithin cross Sects. $(1.5 \mu \mathrm{m})$, which were collected on Thermo ScientificTM Polysine adhesion microscope slides. The sections were hot stained with methylene blue for $10 \mathrm{~min}$. They were flushed several times with distilled water, and then sealed in DPX Mountant for histology. The slides were assessed and documented with a BX50 microscope (Olympus) with NIS Elements AR 3.00 NIKON software.

For 5-metC localization the resin was removed with two changes of acetone and the slides were washed in distilled water and PBS pH 7.2. Before immunocytochemical reactions the sections were incubated with $0.1 \%$ RNAse for $30 \mathrm{~min}$ at $37^{\circ} \mathrm{C}$ and washed in PBS pH $7.2(3 \times 5 \mathrm{~min} ., 30 \mathrm{~min}$ at $\left.37^{\circ} \mathrm{C}\right)$. After neutralization of the medium with $0.1 \mathrm{M} \mathrm{Na}_{2} \mathrm{~B}_{4} \mathrm{O}_{7} \times 10 \mathrm{H}_{2} \mathrm{O}(10 \mathrm{~min}$ at room temperature), the sections were incubated with anti-5-metC mouse (Abcam) primary antibody (1:200 in 1\% BSA in PBS pH 7.2 for $12 \mathrm{~h}$ at $4^{\circ} \mathrm{C}$ ) and secondary goat anti-mouse antibody Alexa Fluor 488 (Invitrogen) diluted $1: 1000$ in $1 \% \mathrm{BSA}-1 \mathrm{~h}$ at $37^{\circ} \mathrm{C}$. DNA was stained with 4,6-diamidino-2-phenylindole (DAPI; Fluka). Finally, the sections were washed in PBS pH 7.2 , dried at room temperature and covered with ProLongTMGold antifade reagent (Thermo Fisher Scientific). The control reactions omitted the incubation with primary antibodies. Semithin sections were analyzed with an Olympus BX50 fluorescence microscope, with a UPlanFI 1009 (N.A. 1.3) oil immersion lens and narrow band filters (U-MNU, U-MNG). The results were recorded with an Olympus XC50 digital color camera and CellB software (Olympus Soft Imaging Solutions $\mathrm{GmbH}$, Germany).

Quantitative evaluation of 5-metC content

The quantitative measurements of 5-metC levels were performed in the root apex cells. For this study, each experiment was carried out at the same temperature, incubation times, and antibody concentrations (Kozłowska et al. 2016). ImageJ (1.47v) software was used for image processing and analysis. Before quantification of the fluorescence intensity, the background was eliminated by adjusting a threshold according to autofluorescence based on the negative control. The fluorescence intensity was measured for five semithin sections per experimental variant at the same magnification and constant exposure time to ensure comparable results. For each zone of the root apex 15 to 30 cells were analyzed depending on the experiment. The level of fluorescence was expressed in arbitrary units (as mean intensity per $\mu \mathrm{m}^{2}$ ). Figures were prepared in Microsoft Excel 2010.

DNA extraction and Methylation-Sensitive Amplified Polymorphism (MSAP) procedure

Tissues for the MSAP procedure were collected from three biological replicates. Each replicate consisted of leaves (second leaf) and the whole root system from three individual plants per treatment combination (control, Mn only, a combination of Mn and Se, and Se only). The leaves and roots were homogenized in liquid nitrogen and subjected to DNA extraction using micro-CTAB method (Doyle and Doyle 1987). Then, $250 \mu \mathrm{g}$ of DNA were used for restriction with two combinations of enzymes in $10 \mu \mathrm{l}$ of the reaction mixture: HpaII / EcoRI and MspI / EcoRI (New England Biolabs) in $1 \times$ CutSmart Buffer with 1.25 $\mathrm{U}$ of each of the restriction enzymes. The restriction reaction was run at $37{ }^{\circ} \mathrm{C}$ for $3 \mathrm{~h}$ with subsequent inactivation of the enzymes at $70{ }^{\circ} \mathrm{C}$ for $10 \mathrm{~min}$. Two technical replications of both restriction combinations were used to cut each DNA sample. The restriction fragments were then subjected to $16 \mathrm{~h}$ of adapter 
ligation at $37{ }^{\circ} \mathrm{C}$, by adding $6 \mu \mathrm{l}$ of a mix containing $30 \mathrm{pmol}$ of HpaII/MspI adapter, 3 pmol of EcoRI adapter (Table A1), 0.6 U of T4 DNA ligase (Thermo Fischer Scientific) and $1 \times \mathrm{T} 4$ DNA ligase buffer. Then, $1 \mathrm{ml}$ of DNA after ligation was used for preamplification reaction ( $10 \mathrm{ml}$ of total volume) and mixed with $15 \mathrm{ng}$ of $\mathrm{HpaII} / \mathrm{MspI}+\mathrm{T}$ and $\mathrm{Eco}+\mathrm{A}$ primers (Table A1), $200 \mathrm{mM}$ of each dNTPs (Promega), $0.25 \mathrm{U}$ Taq polymerase (DreamTaq, ThermoFischer Scientific) and $1 \times$ PCR buffer. The PCR conditions were as follows: 20 cycles of $30 \mathrm{~s}$ at $94{ }^{\circ} \mathrm{C}, 40 \mathrm{~s}$ at $56{ }^{\circ} \mathrm{C}$ and $50 \mathrm{~s}$ at $72{ }^{\circ} \mathrm{C}$. The preamplified DNA was diluted 10 times and $2.5 \mu \mathrm{l}$ were taken as a template for the selective amplification. In this step, $0.5 \mathrm{pmol}$ of EcoRI selective primer labeled with a fluorescent dye IRD 800 (MWG), $12.5 \mathrm{ng}$ of MseI primer, $200 \mu \mathrm{M}$ of each dNTPs (Amersham Pharmacia), 0.3 $\mathrm{U}$ of Taq polymerase (DreamTaq, ThermoFischer Scientific), $1 \mathrm{mM} \mathrm{MgCl}{ }_{2}$ and $1 \times$ PCR buffer supplemented with $2 \mathrm{mM} \mathrm{MgCl}_{2}$ were used in a total volume of $10 \mu \mathrm{l}$ reaction. The PCR was performed in the following conditions: 12 cycles of "touchdown" PCR of $30 \mathrm{~s}$ at $94{ }^{\circ} \mathrm{C}, 30 \mathrm{~s}$ at $68{ }^{\circ} \mathrm{C}$ (decreasing $0.7{ }^{\circ} \mathrm{C}$ per cycle) and $1 \mathrm{~min}$ at 72 , followed by 23 cycles of $30 \mathrm{~s}$ at $94{ }^{\circ} \mathrm{C}, 30 \mathrm{~s}$ at $59{ }^{\circ} \mathrm{C}$, and $1 \mathrm{~min}$ at $72{ }^{\circ} \mathrm{C}$. All together 11 selective primer combinations were used in the analysis (Table A2). After the PCR, $4 \mu \mathrm{l}$ of formamide gel loading buffer were added into the samples and, after denaturation at $95{ }^{\circ} \mathrm{C}$ for $3 \mathrm{~min}$, $0.8 \mu \mathrm{l}$ samples were loaded into polyacrylamide gels composed of 6\% acrylamide/bis-acrylamide 19:1 solution (Sigma), 7 M urea (Amersham Pharmacia), and $1 \times$ TBE buffer. Li-Cor DNA sequencer was used for the electrophoresis at the following parameters: $1400 \mathrm{~V}, 30 \mathrm{~mA}, 30 \mathrm{~W}$. Medium speed of a laser scanning was used.

\section{MSAP data analysis}

To describe the changes in DNA methylation all MSAP bands that met the following two conditions were analyzed: (i) the band pattern was replicable in two technical replications of each DNA sample and (ii) the same band pattern was present in all three biological replicates representing particular treatment combination. Several profiles in MSAP loci were possible: (i) monomorphic loci, characterized by the presence of a band in all samples and in both restriction enzymes combinations; (ii) polymorphic loci of type I, characterized by the presence of a band in one restriction enzyme combination and the lack of a band in the second combination, while this presence/absence of a band was identical for all DNA samples. These loci reflected particular methylation status of cytosines in CCGG sequence recognized by HpaII and MspI restriction enzymes, but were unrelated to any methylation changes triggered by the treatment; (iii) polymorphic loci of type II, characterized by differences in the band pattern between treatment combinations, reflecting methylation changes in CCGG sequence related to the growth conditions. Only the last category of MSAP loci was taken into consideration.

The analysis of methylation changes was based on differences in sensitivity to cytosine methylation in CCGG sequence displayed by HpaII and MspI isoschizomers. Briefly, both enzymes can cleave non-methylated CCGG sequence. HpaII can also cut this sequence when external cytosine is hemimethylated (Mann and Smith 1977; Reyna-Lopez et al. 1997), and MspI is capable of cleaving this site when one or two internal cytosines are methylated (Reyna-Lopez et al. 1997). Such a profile does not allow for identification of the methylation status of each cytosine in CCGG sequence with a perfect precision. It allows, however, for quantification of the most probable changes in methylation using one of the existing models of MSAP data interpretation. In our analysis, we followed the model proposed by Bednarek et al. (2017) which takes into consideration all possible methylation statuses of both external and internal cytosines in CCGG sequence that may underline the presence or the lack of MSAP band after HpaII and MspI digestion. Based on this model, the percentage of demethylation (later encoded as de-Met) and de novo methylation (de novo-Met) events that may occur after a particular treatment vs. the control conditions was calculated. Additionally, this model also allows for quantifying the probable share of demethylation and de novo methylation of cytosines at symmetric $\mathrm{CHG}$ and $\mathrm{CG}$ sites (later encoded as de-Met-CHG and de-MetCG or de novo-Met-CHG and de novo-Met-CG). A more detailed description of the data quantification method is provided in the Supplemental Tables. 
Statistical analysis

The results of biological experiments were reported as an average of triplicate repetitions $( \pm S D)$ and analyzed statistically using one-way ANOVA, followed by post-hoc (Duncan test) comparisons with Statistica Software version 9.1 (SAS Institute Inc., Cary, NC, USA). The significance level was set at $\mathrm{p}<0.05$.

\section{Results}

Biochemical analysis

No significant visual differences between the tested cultivars were found in the seedlings grown under the control conditions. This was also demonstrated in the similarities of the fresh weight of their leaves and roots. Only a slightly higher weight (statistically insignificant) was recorded in cv. Nimfa's leaves as compared with cv. Alibi (Table 1). Growth in the presence of Mn decreased the weight of both leaves and roots by about three times (leaves) or about seven times (roots), independently of the cultivar. Moreover, both cultivars showed signs of leaf edge yellowing. Damage was also visible in the root system, mainly in cv. Alibi. In this cultivar, shortening and deformation of the root system and its stronger browning were more significant than in cv. Nimfa. In Mn + Se media, a weight increase of the examined organs was noted as compared with $\mathrm{Mn}$ only treatment. For plants grown on the media containing only $\mathrm{Se}$, fresh weight of both leaves and roots was comparable to that of the control.

The control seedlings accumulated a greater amount of $\mathrm{Mn}$ in the roots than in the leaves (Table 1). The cultivation on Mn-containing media resulted in a significant increase in the content of this element in both organs, especially in the root systems of the investigated cultivars. The changes were more pronounced in cv. Nimfa than in cv. Alibi. Following joint application of $\mathrm{Mn}$ and $\mathrm{Se}, \mathrm{Mn}$ level slightly increased in the leaves and decreased in the roots of cv. Nimfa, while in cv. Alibi the opposite effect was observed (as compared with Mn treatment). The presence of Se alone did not affect the content of $\mathrm{Mn}$ in
Table 1 Fresh weight $[\mathrm{g}]$ and concentration of elements: $\mathrm{Ca}, \mathrm{Mg}, \mathrm{K}, \mathrm{P}, \mathrm{S}$ and $\mathrm{Mn}\left[\mathrm{mg} \bullet \mathrm{g}^{-1} \mathrm{DW}\right]$ and $\mathrm{Cu}, \mathrm{Zn} \mathrm{Fe}$ and $\mathrm{Se}$ $\left[\mu \mathrm{g} \bullet \mathrm{g}^{-1} \mathrm{DW}\right]$ in the leaves and roots of cvs. Alibi and Nimfa in control plants and after treatment with $10 \mathrm{mM} \mathrm{MnCl}_{2}, 10 \mathrm{mM}$ $\mathrm{MnCl}_{2}+15 \mu \mathrm{M} \mathrm{SeCl}_{2}$ and $15 \mu \mathrm{M} \mathrm{SeCl}_{2}$

\begin{tabular}{|c|c|c|c|c|c|c|c|c|c|c|c|c|}
\hline & & Fresh weight & Mn & $\mathrm{Se}$ & $\mathrm{Ca}$ & $\mathrm{Mg}$ & $\mathrm{K}$ & $\mathrm{P}$ & S & $\mathrm{Cu}$ & $\mathrm{Zn}$ & $\mathrm{Fe}$ \\
\hline \multicolumn{13}{|l|}{ Leaves } \\
\hline \multirow[t]{4}{*}{ cv Alibi } & control & $0.423^{\mathrm{a}}$ & $0.21^{\mathrm{c}}$ & $0.01^{\mathrm{c}}$ & $5.88^{\mathrm{a}}$ & $3.60^{\mathrm{a}}$ & $89.81^{\mathrm{b}}$ & $14.80^{\mathrm{a}}$ & $7.32^{\mathrm{b}}$ & $15.94^{\mathrm{a}}$ & $95.94^{\mathrm{a}}$ & $212.08^{\mathrm{b}}$ \\
\hline & $\mathrm{Mn}$ & $0.131^{\mathrm{c}}$ & $6.63^{\mathrm{a}}$ & $0.01^{\mathrm{c}}$ & $1.41^{\mathrm{c}}$ & $1.35^{\mathrm{b}}$ & $53.23^{\mathrm{d}}$ & $8.45^{\mathrm{b}}$ & $4.24^{\mathrm{c}}$ & $3.96^{\mathrm{c}}$ & $16.68^{\mathrm{c}}$ & $90.76^{\mathrm{c}}$ \\
\hline & $\mathrm{Mn}+\mathrm{Se}$ & $0.165^{\mathrm{b}}$ & $5.32^{\mathrm{b}}$ & $0.08^{\mathrm{b}}$ & $1.00^{\mathrm{d}}$ & $1.19^{c}$ & $57.27^{\mathrm{c}}$ & $7.34^{\mathrm{c}}$ & $4.07^{\mathrm{d}}$ & $2.86^{\mathrm{d}}$ & $17.84^{\mathrm{b}}$ & $78.60^{\mathrm{d}}$ \\
\hline & $\mathrm{Se}$ & $0.430^{\mathrm{a}}$ & $0.21^{\mathrm{c}}$ & $0.21^{\mathrm{a}}$ & $4.85^{\mathrm{b}}$ & $3.62^{\mathrm{a}}$ & $95.50^{\mathrm{a}}$ & $14.91^{\mathrm{a}}$ & $12.25^{\mathrm{a}}$ & $14.27^{\mathrm{b}}$ & $95.66^{\mathrm{a}}$ & $278.90^{\mathrm{a}}$ \\
\hline \multirow[t]{4}{*}{ cv Nimfa } & control & $0.466^{\mathrm{a}}$ & $0.17^{\mathrm{c}}$ & $0.00^{\mathrm{c}}$ & $6.49^{\mathrm{a}}$ & $4.05^{\mathrm{a}}$ & $89.68^{\mathrm{b}}$ & $12.97^{\mathrm{a}}$ & $5.88^{\mathrm{b}}$ & $10.68^{\mathrm{a}}$ & $99.64^{\mathrm{a}}$ & $230.08^{\mathrm{a}}$ \\
\hline & $\mathrm{Mn}$ & $0.137^{\mathrm{c}}$ & $9.81^{\mathrm{b}}$ & $0.00^{c}$ & $1.71^{\mathrm{d}}$ & $1.50^{\mathrm{d}}$ & $59.18^{\mathrm{c}}$ & $8.57^{\mathrm{c}}$ & $3.86^{\mathrm{d}}$ & $5.49^{c}$ & $24.33^{\mathrm{d}}$ & $80.16^{\mathrm{c}}$ \\
\hline & $\mathrm{Mn}+\mathrm{Se}$ & $0.176^{\mathrm{b}}$ & $12.26^{\mathrm{a}}$ & $0.08^{\mathrm{b}}$ & $2.18^{\mathrm{c}}$ & $1.79^{\mathrm{c}}$ & $48.96^{\mathrm{d}}$ & $7.46^{\mathrm{d}}$ & $4.25^{\mathrm{c}}$ & $3.62^{\mathrm{d}}$ & $26.68^{\mathrm{c}}$ & $70.96^{\mathrm{d}}$ \\
\hline & $\mathrm{Se}$ & $0.465^{\mathrm{a}}$ & $0.15^{\mathrm{c}}$ & $0.18^{\mathrm{a}}$ & $4.94^{\mathrm{b}}$ & $3.22^{\mathrm{b}}$ & $91.99^{\mathrm{a}}$ & $10.90^{\mathrm{b}}$ & $9.23^{\mathrm{a}}$ & $10.56^{\mathrm{b}}$ & $58.80^{\mathrm{b}}$ & $197.53^{b}$ \\
\hline \multicolumn{13}{|l|}{ Roots } \\
\hline \multirow[t]{4}{*}{ cv Alibi } & control & $0.247^{\mathrm{a}}$ & $0.37^{\mathrm{c}}$ & $0.00^{\mathrm{b}}$ & $1.85^{\mathrm{b}}$ & $1.51^{\mathrm{a}}$ & $67.84^{\mathrm{b}}$ & $7.65^{\mathrm{d}}$ & $3.87^{\mathrm{c}}$ & $51.74^{\mathrm{b}}$ & $71.31^{\mathrm{d}}$ & $1316.38^{\mathrm{a}}$ \\
\hline & $\mathrm{Mn}$ & $0.035^{\mathrm{d}}$ & $13.76^{\mathrm{b}}$ & $0.00^{\mathrm{b}}$ & $1.49^{c}$ & $1.11^{\mathrm{c}}$ & $40.82^{c}$ & $9.54^{\mathrm{b}}$ & $5.33^{\mathrm{b}}$ & $27.09^{d}$ & $83.36^{\mathrm{b}}$ & $1041.06^{c}$ \\
\hline & $\mathrm{Mn}+\mathrm{Se}$ & $0.056^{\mathrm{c}}$ & $18.16^{\mathrm{a}}$ & $0.09^{\mathrm{a}}$ & $3.03^{\mathrm{a}}$ & $1.26^{\mathrm{b}}$ & $41.04^{\mathrm{c}}$ & $9.80^{\mathrm{a}}$ & $5.98^{\mathrm{a}}$ & $32.03^{c}$ & $86.58^{\mathrm{a}}$ & $1210.26^{b}$ \\
\hline & $\mathrm{Se}$ & $0.203^{\mathrm{b}}$ & $0.27^{\mathrm{d}}$ & $0.08^{\mathrm{a}}$ & $1.87^{\mathrm{b}}$ & $1.50^{\mathrm{a}}$ & $77.35^{\mathrm{a}}$ & $7.87^{\mathrm{c}}$ & $3.89^{c}$ & $74.29^{\mathrm{a}}$ & $82.51^{\mathrm{c}}$ & $1140.36^{c}$ \\
\hline \multirow[t]{4}{*}{ cv Nimfa } & control & $0.238^{\mathrm{a}}$ & $0.35^{\mathrm{c}}$ & $0.00^{\mathrm{b}}$ & $1.28^{\mathrm{d}}$ & $1.65^{\mathrm{b}}$ & $69.85^{\mathrm{a}}$ & $7.48^{\mathrm{c}}$ & $4.17^{\mathrm{c}}$ & $66.14^{\mathrm{a}}$ & $70.00^{c}$ & $1546.79^{b}$ \\
\hline & $\mathrm{Mn}$ & $0.041^{\mathrm{d}}$ & $16.03^{\mathrm{a}}$ & $0.00^{\mathrm{b}}$ & $2.76^{\mathrm{a}}$ & $1.30^{\mathrm{c}}$ & $34.97^{\mathrm{c}}$ & $8.04^{b}$ & $5.08^{\mathrm{a}}$ & $20.67^{\mathrm{c}}$ & $98.61^{\mathrm{a}}$ & $903.09^{d}$ \\
\hline & $\mathrm{Mn}+\mathrm{Se}$ & $0.057^{\mathrm{c}}$ & $15.31^{\mathrm{b}}$ & $0.06^{\mathrm{a}}$ & $2.01^{\mathrm{b}}$ & $1.24^{\mathrm{d}}$ & $34.65^{\mathrm{c}}$ & $8.38^{\mathrm{a}}$ & $5.02^{\mathrm{b}}$ & $18.29^{\mathrm{d}}$ & $69.53^{\mathrm{d}}$ & $1003.73^{c}$ \\
\hline & $\mathrm{Se}$ & $0.210^{\mathrm{b}}$ & $0.24^{\mathrm{d}}$ & $0.06^{\mathrm{a}}$ & $1.73^{\mathrm{c}}$ & $1.71^{\mathrm{a}}$ & $64.81^{\mathrm{b}}$ & $7.10^{\mathrm{d}}$ & $3.17^{\mathrm{d}}$ & $51.14^{\mathrm{b}}$ & $75.95^{\mathrm{b}}$ & $2403.00^{\mathrm{a}}$ \\
\hline
\end{tabular}

The same letters indicate not significant differences between treatments registered separately for each wheat genotype $(\mathrm{p} \leq 0.5)$ 
the leaves of any cultivar, but decreased Mn concentration in the root systems.

An analysis of Se content in the tested cultivars showed only trace amounts of this element in the control and Mn variants. In the roots, Se administration, both alone and with $\mathrm{Mn}$, increased Se content by about six to nine times for cv. Nimfa and cv. Alibi, respectively. In the leaves, the presence of Mn more than doubled decreased the Se uptake, as compared with Se added individually, especially in cv. Alibi.

The studied cultivars differed in their content of macro- and micronutrients (Table 1). In the control leaves of cv. Nimfa, higher concentrations of $\mathrm{Ca}, \mathrm{Mg}$, $\mathrm{Zn}$ and $\mathrm{Fe}$ were recorded than in cv. Alibi, while the root system of cv. Nimfa was richer in $\mathrm{Mg}, \mathrm{S}, \mathrm{Cu}$ and Fe than that of cv. Alibi. Mn presence restricted the accumulation of all tested elements in the leaves of both cultivars. In the root system, an increase in the content of $\mathrm{P}, \mathrm{S}$ and $\mathrm{Zn}$ (both cultivars) and $\mathrm{Ca}$ (cv. Nimfa) was recorded. Simultaneous treatment with $\mathrm{Mn}$ and Se reduced the content of $\mathrm{P}, \mathrm{Cu}$ and $\mathrm{Fe}$ in the leaves of the tested cultivars and additionally of $\mathrm{K}$ in cv. Nimfa, in comparison with the plants exposed to $\mathrm{Mn}$ alone. Moreover, in the leaves of cv. Alibi a drop in the content of $\mathrm{Ca}, \mathrm{Mg}$ and $\mathrm{S}$, was noticed. In the root system, there was an increase in the level of $\mathrm{P}$ and $\mathrm{Fe}$ for both cultivars, while the concentration of the other elements decreased in cv. Nimfa and rose in cv. Alibi (as compared with Mn alone). In the presence of Se alone, the content of all elements in both leaves and roots was close to that recorded for the controls.

An analysis of $\mathrm{H}_{2} \mathrm{O}_{2}$ level indicated its much more abundant presence in the leaves than in the roots of all studied plants (Fig. 1A). In control plants, no significant differences in the content of this compound between the tested plants were found. After treatment with $\mathrm{Mn}$ both cultivars showed increased concentration of $\mathrm{H}_{2} \mathrm{O}_{2}$ in the leaves, and in cv. Alibi it rose by about 1.5 times. In the roots of both cultivars the content of $\mathrm{H}_{2} \mathrm{O}_{2}$ grew by about three to five times (more in cv. Nimfa). When $\mathrm{Mn}$ and $\mathrm{Se}$ were administered simultaneously, the concentration of $\mathrm{H}_{2} \mathrm{O}_{2}$ in the leaves of both cultivars decreased in relation to that observed for Mn (especially in cv. Alibi). In the roots, hydrogen peroxide level changed only to a small extent as compared with Mn-only treatment. The presence of Se added individually did not significantly affect the
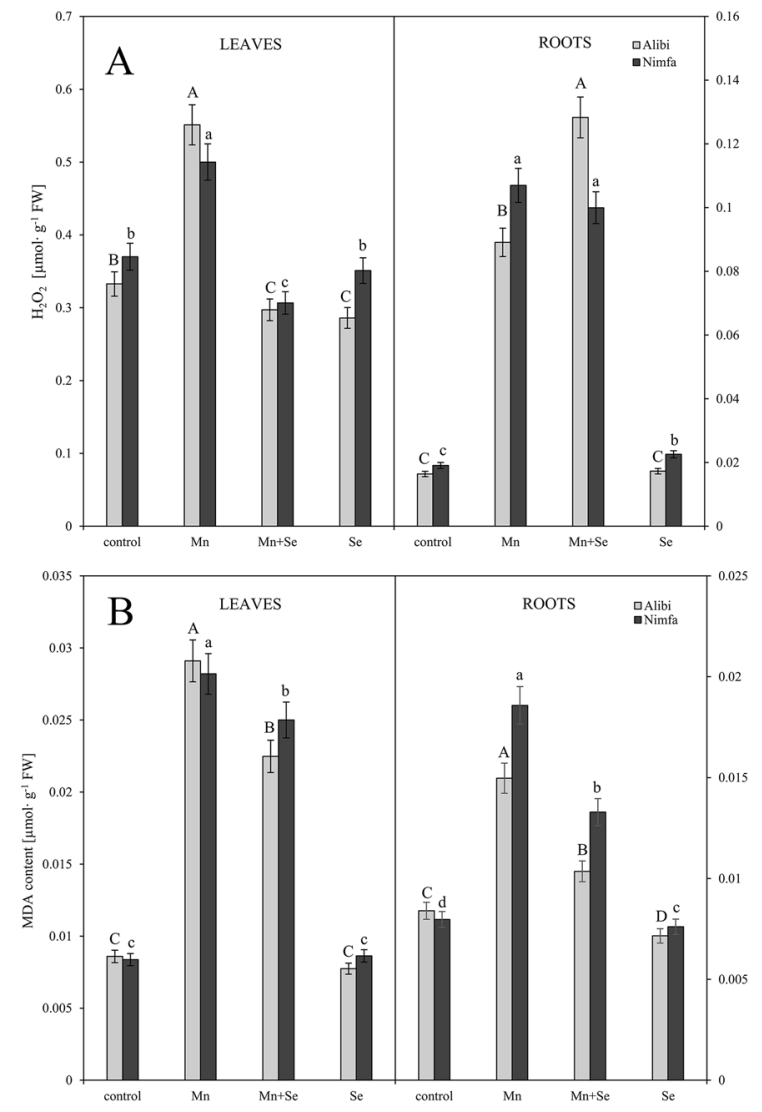

Fig. $1 \mathrm{H}_{2} \mathrm{O}_{2}\left[\mu \mathrm{mol} \mathrm{g}{ }^{-1} \mathrm{FW}\right]-\mathrm{A}$ and malondialdehyde (MDA) $\left[\mu \mathrm{mol} \mathrm{g}{ }^{-1} \mathrm{FW}\right]-\mathrm{B}$ content in the leaves and roots of cvs. Alibi and Nimfa in control plants and after treatment with $10 \mathrm{mM}$ $\mathrm{MnCl}_{2}, 10 \mathrm{mM} \mathrm{MnCl}+15 \mu \mathrm{M} \mathrm{SeCl} 2$ and $15 \mu \mathrm{M} \mathrm{SeCl}$. Data are averages from three independent biological replications $\pm \mathrm{SE}$. The same letters indicate not significant differences between treatments $(p \leq 0.5)$

level of $\mathrm{H}_{2} \mathrm{O}_{2}$ of the studied cultivars and its concentration in both leaves and roots was close to that in the control.

The change in MDA level, which is considered an indicator of the level of lipid oxidation by ROS, was slightly higher in cv. Alibi both in the roots and leaves (Fig. 1B). After growing in Mn media, MDA increased by about three times in the leaves and by about 1.5-2 times in the roots of both wheat cultivars. Cultivation on $\mathrm{Mn}+\mathrm{Se}$ media diminished MDA values in all tested cultivars, as compared with Mnonly conditions, except for cv. Nimfa leaves, where no significant differences between $\mathrm{Mn}+\mathrm{Se}$ and $\mathrm{Mn}$ treatment were found. $\mathrm{Cv}$. Nimfa plants grown on Se-only media had similar MDA levels to controls in 
both leaves and roots, while in cv. Alibi a decrease in MDA (vs. control) was registered.

The contents of soluble sugars and starch are presented in Table 2. Control leaves of both cultivars contained similar levels of starch, while significantly higher values of soluble sugars were found in cv. Alibi. In Mn-only media, an increase in the level of both simple and compound carbohydrates was indicated. It was especially visible for soluble sugars, the amount of which spiked five times following the metal treatment. Joint treatment with $\mathrm{Mn}$ and Se caused a drop in starch concentration (vs. Mn-only variant) in both cultivars. The presence of Se, as the only supplement to the media, did not significantly affect the concentration of any tested carbohydrates.

Microscopic observations and analysis of DNA methylation

Microscopic observations after staining with tolouidine blue revealed numerous chloroplasts in the mesophyll cells of both cultivars grown under control conditions (a representative example is shown in Fig. 2A). Figure 2A' shows chloroplasts localized under the membrane uniformly stained with toluidine blue. The unstained areas of the plastids indicate the presence of starch grains. Mn induced visible changes in the chloroplasts, as it boosted starch accumulation and the formation of amyloplasts in mesophyll cells (Fig. 2B, C, D). In cv. Alibi the response varied widely, ranging from slight changes

Table 2 The sugars content $\left[\mathrm{mg}_{\bullet} \mathrm{g}^{-1} \mathrm{DW}\right]$ in the leaves of cvs. Alibi and Nimfa in control plants and after treatment with $10 \mathrm{mM} \mathrm{MnCl} 2,10 \mathrm{mM} \mathrm{MnCl}{ }_{2}+15 \mu \mathrm{M} \mathrm{SeCl}_{2}$ and $15 \mu \mathrm{M}$ $\mathrm{SeCl}_{2}$

\begin{tabular}{llll}
\hline & & Soluble sugars & Starch \\
\hline cv Alibi & control & $0.127^{\mathrm{c}}$ & $0.390^{\mathrm{d}}$ \\
& Mn & $0.537^{\mathrm{a}}$ & $0.624^{\mathrm{a}}$ \\
& Mn+Se & $0.463^{\mathrm{b}}$ & $0.611^{\mathrm{b}}$ \\
& Se & $0.136^{\mathrm{d}}$ & $0.404^{\mathrm{c}}$ \\
& control Nimfa & $0.101^{\mathrm{c}}$ & $0.395^{\mathrm{c}}$ \\
& Mn & $0.621^{\mathrm{a}}$ & $0.625^{\mathrm{a}}$ \\
& Mn $+\mathrm{Se}$ & $0.420^{\mathrm{b}}$ & $0.608^{\mathrm{b}}$ \\
& Se & $0.121^{\mathrm{c}}$ & $0.337^{\mathrm{d}}$ \\
\hline
\end{tabular}

The same letters indicate not significant differences between treatments registered separately for each wheat genotype $(p \leq 0.5)$ in the plastids where starch accumulated (Fig. 2B') to complete degeneration of the leaves with numerous amyloplasts in their cells (Fig. 2C, C'). In cv. Nimfa, the vast majority of plastids were changed and accumulated starch (Fig. 2D, D').

In $\mathrm{Mn}+\mathrm{Se}$ variants, plastids in cv. Alibi were mainly amyloplasts (Fig. 2E') or small, nearly uniformly colored structures (Fig. 2E''). In cv. Nimfa, only amyloplasts were found in the cells of the assimilation parenchyma (Fig. 2F, F'). The presence of Se did not change the microscopic image of the leaves in any of the cultivars, which was the same as that recorded for the control (data not shown).

In the leaves of both wheat cultivars, 5-metC was localized in the cell nuclei of all tissues, i.e., in the epidermis, assimilation mesophyll and vascular bundle (Fig. 3). There were no significant differences in the nucleus signal intensity in the control leaves (Fig. 3A, B) and those grown in the presence of Mn (Fig. 3C, D) and Mn + Se (Fig. 3E, F). Unexpectedly, microscopic analysis of these sections revealed that Mn uptake resulted not only in starch accumulation in mesophyll plastids. The membranes of the transformed plastids showed autofluorescence, which may indicate changes in their structure (Fig. 3C', D'). In either cultivar, chloroplasts observed in the control mesophyll cells did not show autofluorescence (Fig. 3A, B). These changes in plastids were also seen in the leaves of plants grown in the presence of $\mathrm{Mn}+\mathrm{Se}$ (Fig. 3E', F'). In both cultivars, amyloplasts (Fig. 3E and E', $\mathrm{F}$ and F') were mainly localized in the cells of the assimilation parenchyma.

Microscopic observations of the control roots (Fig. 4A) revealed similar anatomy for both cultivars, with the growth apex surrounded by cap cells, and the meristem composed of rows of cuboid-shaped cells (Fig. 4A', A'). Above those, there was a zone of cell extension and differentiation with procambium and procortex layers. In Mn treated plants, the root anatomical structures showed significant differences between the cultivars. In cv. Alibi roots (Fig. 4B), the meristematic cells did not have a regular shape (Fig. 4B') and the apex was surrounded by a smaller number of cap cells, often with irregular shapes and deformed nuclei. Moreover, the area between the meristem and the zone of differentiation comprised groups of oval-shaped cells that were larger than the surrounding cells and absent in the control (Fig. 4B'). 
Fig. 2 Micrographs of sections of wheat leaves grown under control conditions and after treatment with $10 \mathrm{mM} \mathrm{MnCl}_{2}$ and $10 \mathrm{mM}$ $\mathrm{MnCl}_{2}+15 \mu \mathrm{M} \mathrm{SeCl}{ }_{2}$. e - epiderm, m-mesophyll cells, vb - vascular bundle, ch-chloroplast, p—plastid, $\mathrm{n}$-nucleus

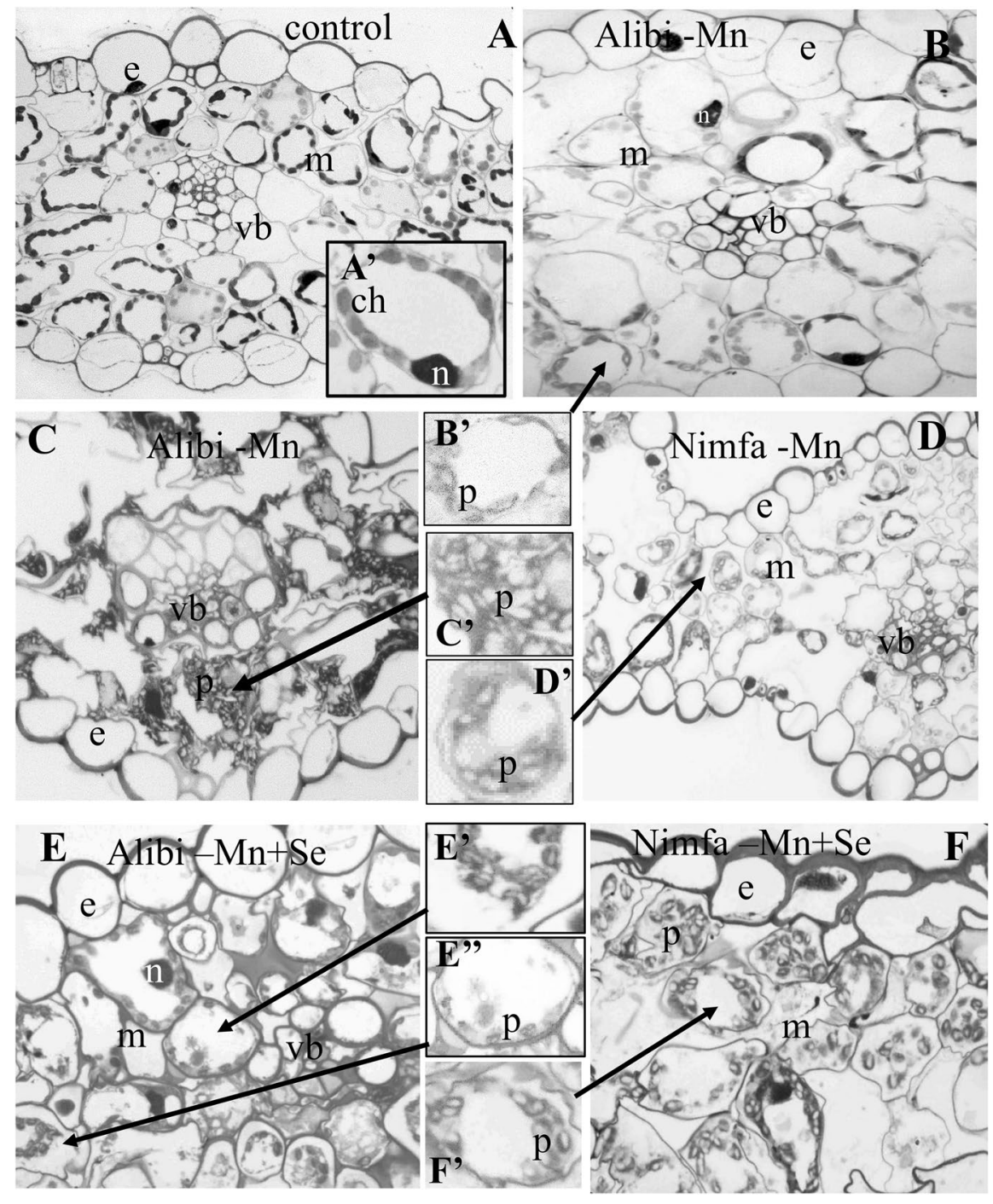

Mn uptake led to drastic anatomical changes in cv. Nimfa roots (Fig. 4C). These changes were often accompanied by degeneration of major growth apexes. In such roots, numerous cap cells were damaged and the meristematic cells were of abnormal shapes without visible nuclei (Fig. 4C',). Additionally, a characteristic group of compact, small cells with large nuclei at the meristem differentiation border was found (Fig. 4C'), which was not observed in the control roots. When $\mathrm{Mn}$ was provided together with Se, the anatomy of the root growth apex in $\mathrm{cv}$. Alibi (Fig. 4D) and cv. Nimfa (Fig. 4E) was more similar to the control, and there were no distinguished groups of cells above the meristem. In cv. Alibi, the meristematic cells were of correct shape (Fig. 4D'), whereas irregularly shaped cells but with visible nuclei were still present in cv. Nimfa (Fig. 4E').

In the roots a similar pattern of 5-metC localization (Fig. 5.I.A-C) and levels (Fig. 6A and B) was observed in the plants grown under control conditions. A very weak signal was localized in the meristematic and cap cells (Fig. 5.I.A). A successive increase in 5-metC was found in the nuclei of cells that entered the differentiation and elongation pathway (Figs. 5.I.B and C, 6A and B). In the root elongation zone, the strongest signal was detected in the nuclei of the cells of the differentiating vascular cylinder (Fig. 5.I.C). No signal was localized in control material, incubated without anti-5-metC antibodies (data not shown). 
Fig. 3 5-metC localization in Alibi (Fig. A, C, E) and Nimfa (Fig. B, D, F) leaves; a-f DAPI. (vb - vascular bundle, $\mathrm{m}$ - mesophyll cell, $\mathrm{e}$ - epidermis, $\mathrm{n}$ - nucleus, asteris - plastid $) \times 400$. In the control plants $(\mathrm{A}, \mathrm{B})$ and those cultured in the presence of $\mathrm{Mn}(\mathrm{C}, \mathrm{D})$ and $\mathrm{Mn}+\mathrm{Se}(\mathrm{E}, \mathrm{F})$ a similar signal was localized in the nuclei of leaves cells. Control-in both cultivars' chloroplasts did not show autofluorescence (A, B). In the Mn media (C', D') and $\mathrm{Mn}+$ Se media (E', F') autofluorescence of plastids membranes was observed
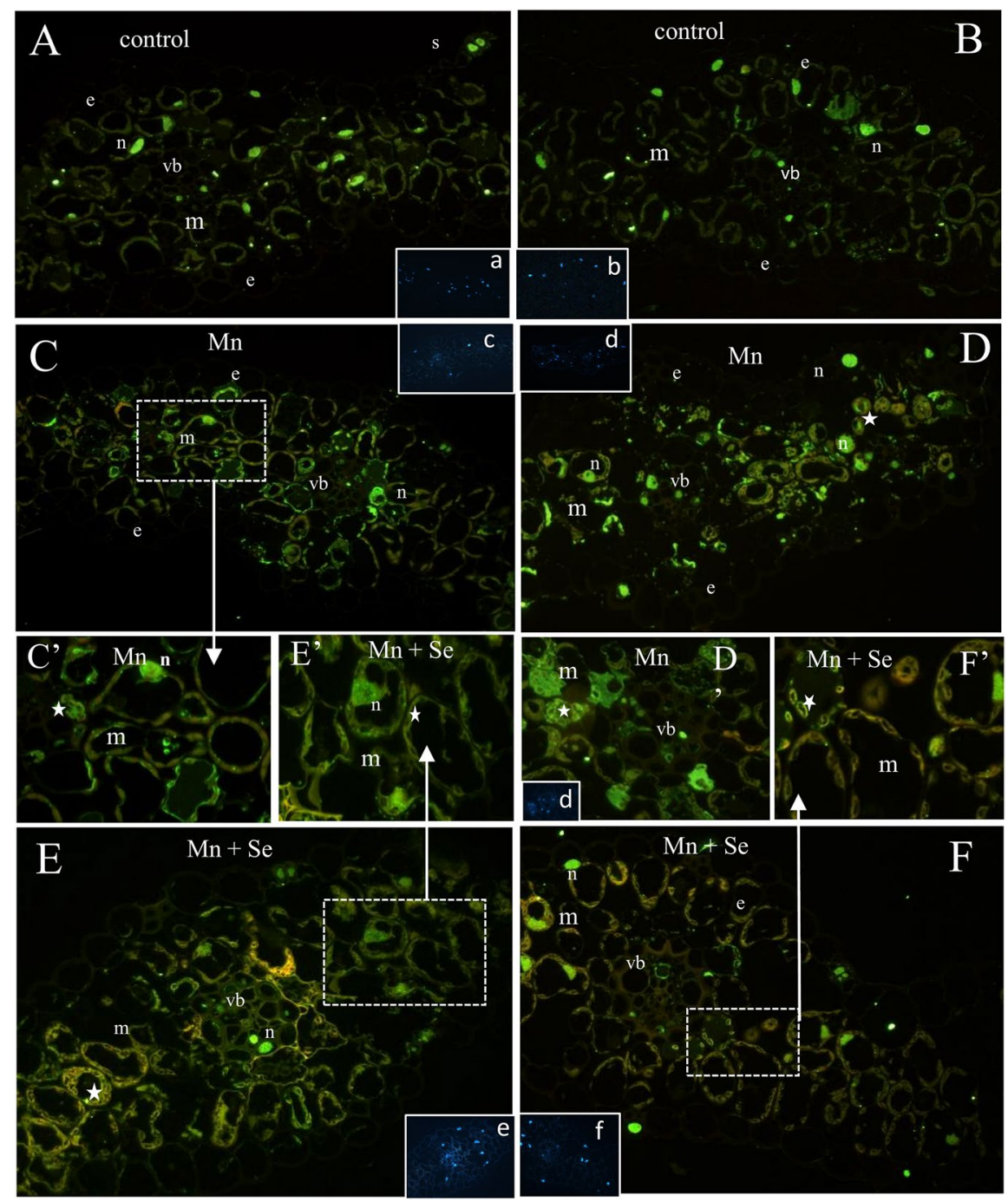

In the roots of cv. Alibi grown in the presence of Mn the increase in DNA methylation was observed from the differentiation zone to cell elongation zone, similarly as in control (Figs. 5.II.A$\mathrm{C}$ and 6A). In the cap and meristematic cells, DNA was only slightly more methylated than in control (Fig. 6A). However, the tissues exhibiting anatomical abnormalities (Fig. 4) showed also changes in their DNA methylation pattern. In the cap zone the enhanced signal was visible only in single cells (Fig. 5.II.A), while the group of oval-shaped cells, not present in control (Fig. 4B'), showed lower level of 5-metC than the surrounding cells (Figs. 5.II.B, 6A - "different cells"). The elevated level of 5-metC was detected only in the cells on the procambium-procortex border (Fig. 5.II.B). In the elongation zone, the cells were irregular, some with no visible nuclei, and some with nuclei with a strong 5-metC signal (Fig. 5.II.C).

Mn uptake leading to anatomical changes in $\mathrm{cv}$. Nimfa roots (Fig. 4) was also reflected in 5-metC signal intensity in the nuclei (Figs. 5.III.A-C, 6B). A significantly stronger signal was detected in the damaged cells of the root apex, i.e., the cap cells with irregular shapes and deformed nuclei and single meristematic cells with nuclei still present (Fig. 5.III.A). Additionally, higher level of 5-metC was found in the specific group of small cells with highly condensed DNA (Fig. 4C') on the meristem - differentiation zone border (Figs. 5.III.B, 6B - “different cells"). 


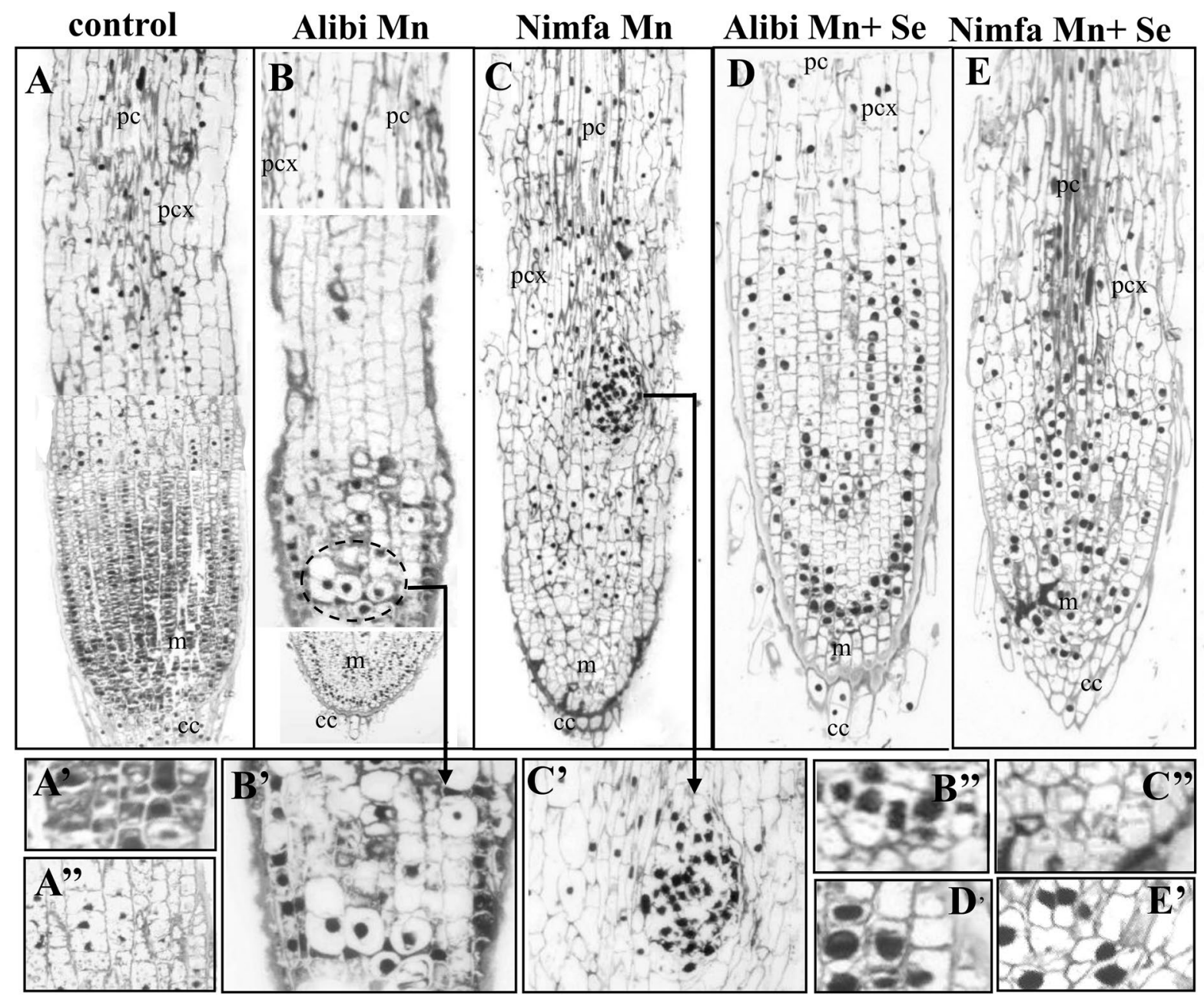

Fig. 4 Microscopic observation of wheat roots grown under control conditions and after treatment with $10 \mathrm{mM} \mathrm{MnCl}_{2}$ and $10 \mathrm{mM}$ $\mathrm{MnCl}_{2}+15 \mu \mathrm{M} \mathrm{SeCl}_{2}$. cc - cap cells, $\mathrm{m}$ - meristem, pc - procambium, pcx - procortex

Cultivation of plants in the presence of $\mathrm{Mn}+\mathrm{Se}$ prevented the previously observed disturbances in the root tissue differentiation (Figs. 4 and 5.IV.A$\mathrm{C}$ and $\mathrm{V} . \mathrm{A}-\mathrm{C}$ ). In cv. Alibi the level of DNA methylation in the meristem and cap zones was similar to that of the control (Figs. 5.IV.A, 6A). In $\mathrm{cv}$. Nimfa, in which the anatomy of these root zones was slightly impaired in some roots (Fig. 4.E), the level of 5-metC was also slightly higher than in control (Figs. 5.V.A, 6B). In both cultivars, no significant disturbances in the differentiation and root elongation zones were found (Fig. 5.IV.B-C, V.B-C) and, similarly to the control, a progressive increase in DNA methylation was observed in the differentiating cells (Fig. 6).
A quantitative assessment of 5-metC level is shown in Fig. 6. In both cultivars, regardless of the treatment, we found an increase in methylation level from the root cap to the differentiation zone. Mn presence generally enhanced methylation intensity. In cv. Alibi, significant changes were restricted to the differentiation zone, while in cv. Nimfa they occurred throughout the root apex. A particular increase in 5-metC was recorded in the root cap (ca. three-fold) and in the apical meristem (ca. 2.5-fold). Under $\mathrm{Mn}+\mathrm{Se}$ conditions, methylation levels were similar to those found in the control.

The analysis of DNA methylation profiles using MSAP method showed no changes in the band pattern in the leaves collected from control plants and 

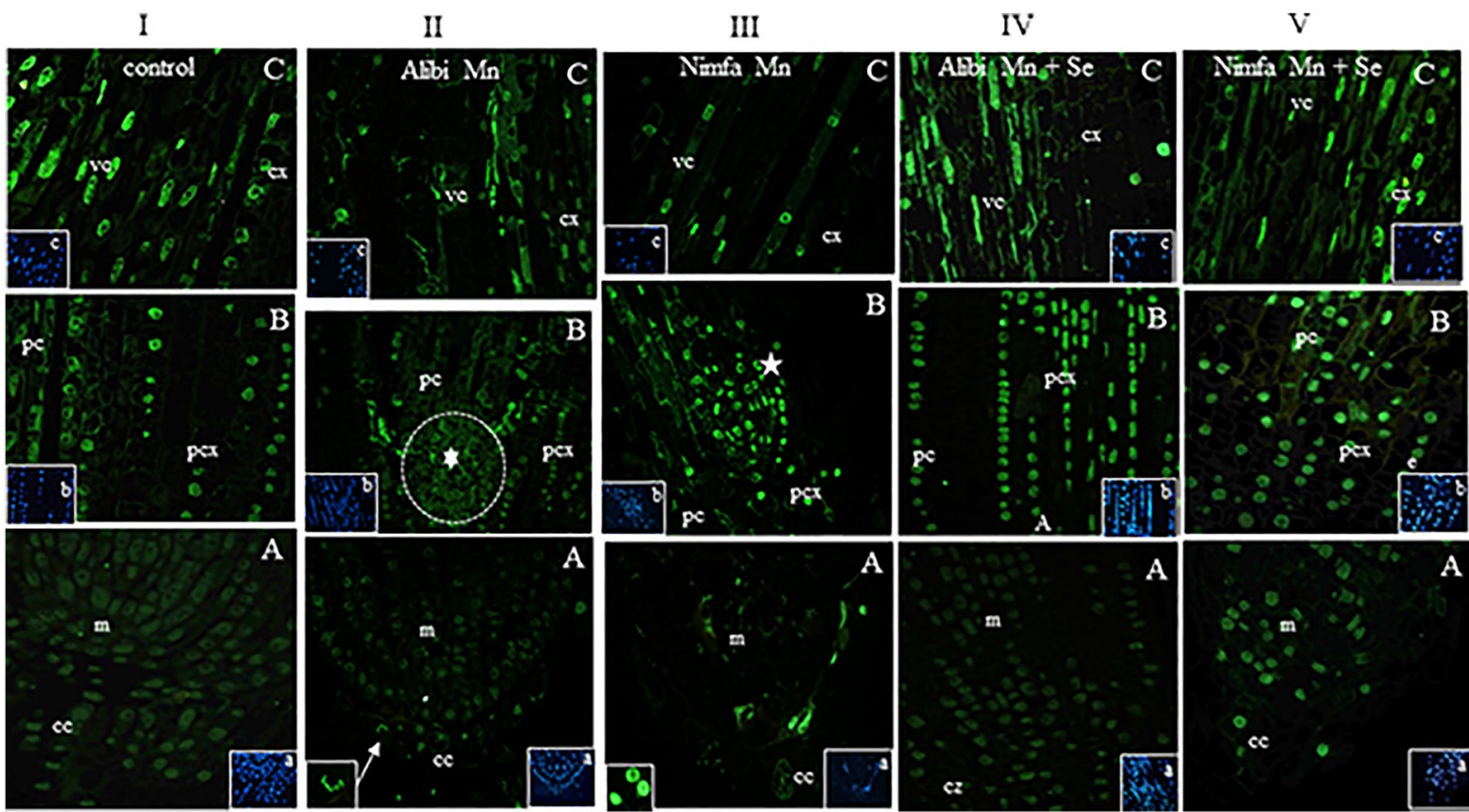

Fig. 5 5-metC localization in the cells of the root growth apex. A - meristem and cap cells, B- differentiation zone, C - elongation zone, a-c DAPI. x 400. I. Control. Very low 5 -metC fluorescence in the meristem and cap cells, signal level increase from the differentiation to elongation zone, II. Alibi Mn. Increased fluorescence in some nuclei of the cap cells (A-insert), a compact group of the cells in the differentiation zone (B-asterisk), in the elongation zone irregularly shaped

from those grown in the presence of $\mathrm{Mn}, \mathrm{Mn}+\mathrm{Se}$ or Se (data not shown). In this organ, only two types of loci were found: monomorphic and polymorphic of type I, which reflected a particular methylation status of cytosines in CCGG sequence recognized by HpaII and MspI restriction enzymes, but unrelated to methylation changes triggered by growth conditions.

Contrary to that, in the roots we found 101 polymorphic loci of type II, representing differences in methylation of CCGG sites. One of these loci was polymorphic between cvs. Alibi and Nimfa, but did not show any methylation changes between the treatments: the bands were present in all cv. Alibi samples and absent in all cv. Nimfa samples, and thus this locus was not taken into account in further analysis. The other two loci also distinguished the cultivars of Alibi and Nimfa. In the first locus, absent in cv. Nimfa, the bands were present in both restriction combinations in cv. Alibi roots treated with a combination of Mn and Se. The second locus was absent in cells are present, III. Nimfa Mn. Strongly damaged meristem and cap cells, high 5-metC signal (inset) in single cells, a compact group of the cells with increased fluorescence in the differentiation zone (B- asterisk), IV. Alibi Mn+Se. A - C The root anatomy and general pattern of location 5-metC similar to that in control. $\mathrm{cc}$ - cap cells, $\mathrm{m}$ - meristem, $\mathrm{pc}$ - procambium, $\mathrm{pcx}$ - procortex, vc-vascular cylinder, $\mathrm{cx}$ - cortex

cv. Alibi, whereas in all cv. Nimfa samples the bands were present after HpaII/EcoRI digestion only. The bands in the remaining loci were present in both cultivars and represented various patterns of MSAP profiles. Altogether 100 polymorphic loci were used to calculate the proportion of demethylation (de-Met) and de novo methylation (de novo-Met) of cytosines at CCGG sites. Additionally, the proportion of symmetric methylation changes of cytosines in CG and $\mathrm{CHG}$ context (where $\mathrm{H}$ represents internal cytosine in CCGG sequence) was estimated taking into account: (i) demethylation of $\mathrm{CHG}$ context (de-Met-CHG), (ii) demethylation of CG context (de-Met-CG), (iii) de novo methylation of CHG context (de novo-Met$\mathrm{CHG}$ ), and (iv) de novo methylation of CG context (de novo-Met-CG).

The methylation status of CCGG sites in cv. Alibi and cv. Nimfa roots was comparable and changed in a similar manner in all treatments in both cultivars (Table 3 ). A higher proportion of 
Fig. 6 5-metC level in the cells of cv. Alibi (A) and Nimfa (B) root growth apex (control, Mn - manganese, $\mathrm{Mn}+\mathrm{Se}-$ manganese + selenium). Data are averages from three independent biological replications $\pm \mathrm{SE}$. The same letters indicate not significant differences between treatments $(p \leq 0.5)$
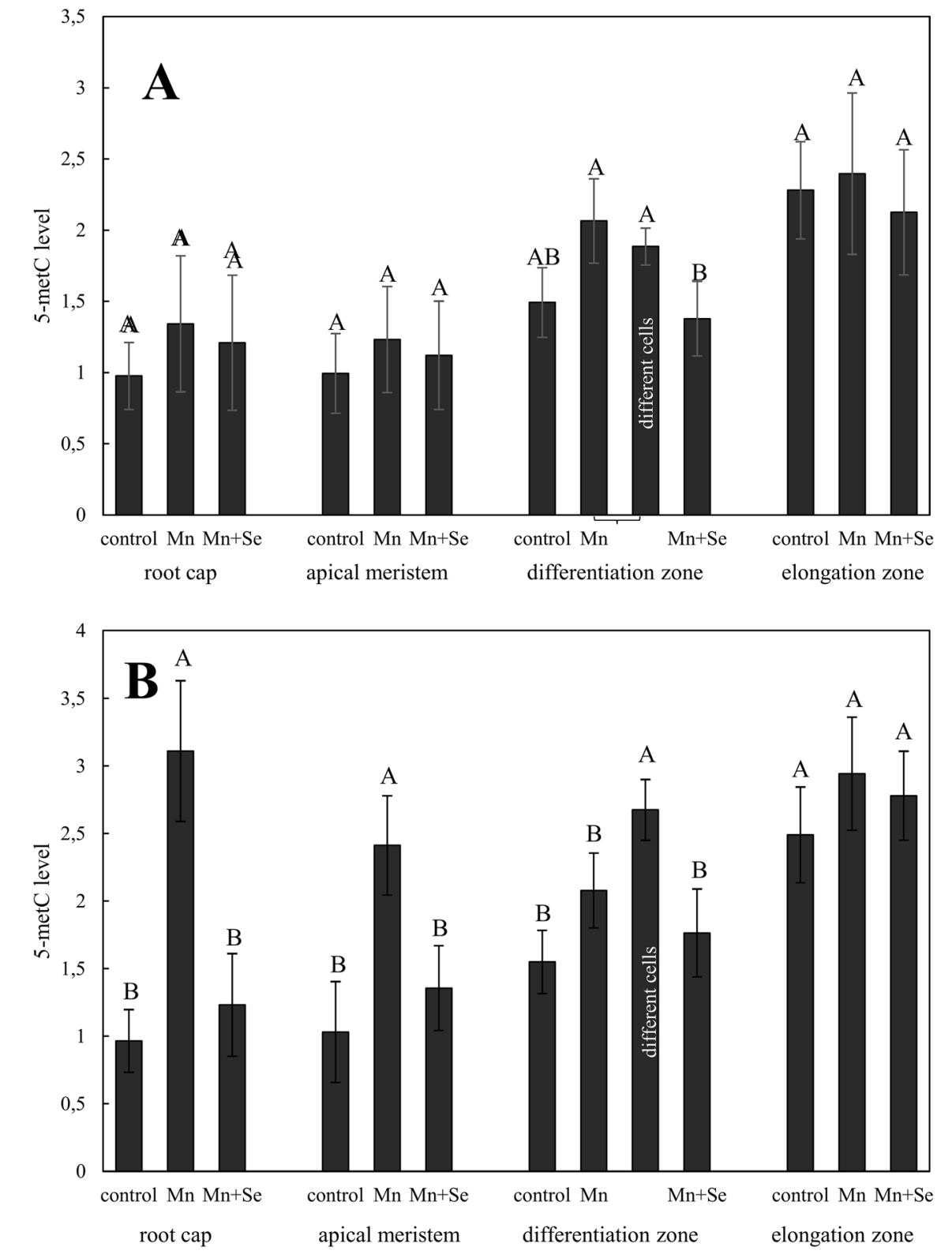

\begin{tabular}{|c|c|c|c|c|c|c|}
\hline \multirow[t]{2}{*}{ Type of the event } & \multicolumn{3}{|l|}{ Nimfa } & \multicolumn{3}{|l|}{ Alibi } \\
\hline & $\mathrm{C}$ vs $\mathrm{Mn}$ & $\mathrm{C}$ vs $\mathrm{Mn}+\mathrm{Se}$ & $\mathrm{C}$ vs Se & $\mathrm{C}$ vs $\mathrm{Mn}$ & $\mathrm{C}$ vs $\mathrm{Mn}+\mathrm{Se}$ & $\mathrm{C}$ vs Se \\
\hline de-Met & 20.18 & 27.70 & 10.80 & 21.06 & 29.70 & 10.32 \\
\hline de novo-Met & 12.16 & 18.01 & 11.01 & 12.15 & 18.32 & 11.94 \\
\hline de-Met-CHG & 9.06 & 15.32 & 1.44 & 9.72 & 16.83 & 1.01 \\
\hline de-Met-CG & 11.12 & 12.38 & 9.36 & 11.34 & 12.87 & 9.31 \\
\hline de novo-Met-CHG & 3.21 & 8.82 & 1.85 & 3.24 & 9.16 & 2.23 \\
\hline de novo-Met-CG & 8.94 & 9.19 & 9.16 & 8.91 & 9.16 & 9.72 \\
\hline
\end{tabular}

Table 3 Comparison of methylation status in cvs. Nimfa and Alibi root samples expressed as the percentage of methylation changes between control samples (C) and each of the treatments (Mn only, $\mathrm{Mn}+\mathrm{Se}$ and Se only). The data are based on all polymorphic MSAP loci 
demethylation than de novo methylation events was detected at CCGG sites after $\mathrm{Mn}$ and $\mathrm{Mn}+\mathrm{Se}$ application regardless of the genotype. At the same time, more changes in methylation status were noticed for the joint treatment with $\mathrm{Mn}$ and Se than for Mn-only treatment. Plant cultivation on the media supplemented with Se alone resulted in the lowest proportion of changes with similar number of demethylation and de novo methylation events. An analysis of the proportion of methylation changes at symmetric cytosines also showed a greater percentage of de-methylation than de novo methylation events at $\mathrm{CHG}$ and CG sites following $\mathrm{Mn}$ treatment. Under $\mathrm{Mn}+\mathrm{Se}$ conditions, the proportion of all tested methylation events increased, especially in the context of de novo methylation of $\mathrm{CHG}$ sites. However, the presence of Se only reduced the amount of methylation changes in comparison with the controls, particularly of demethylation or de novo methylation of CHG context (Table 3).

When the analysis was limited to the 20 polymorphic loci that represented the genotype specific changes in the methylation events, some minor differences in the proportion of methylation changes were noticed as compared with those described above (Table 4). The combined $\mathrm{Mn}+$ Se treatment resulted in a higher proportion of de novo methylations of CCGG sequences in cv. Nimfa roots. Also, Se-only treatment increased the proportion of methylation changes in cvs. Nimfa and Alibi, including the higher number of demethylation or de novo methylation events at CHG and CG context, except for demethylations at $\mathrm{CHG}$ in $\mathrm{cv}$. Alibi roots.

Table 4 The comparison of methylation status in cvs. Nimfa and Alibi root samples expressed as the percentage of methylation changes between control samples (C) and each of the

\section{Discussion}

\section{Biochemical analysis}

The effect of a stressful stimulus on a plant triggers a cascade of signals, the effect of which is the modification of metabolism enabling survival in stressful conditions. Plenty of stress factors trigger similar morphological alteration in plants such as: weight loss, yellowing or browning, as well as tissue deformation and shortening demonstrated i.e., under metal stress by Mishra et al. (2006), Selvaraj (2018), Huang et al. (2019).

In our study, the tissue browning indicated that the applied dose of Mn was stressful for both tested cultivars, and slightly more intense in cv. Alibi. Greater differences between the cultivars involved the response of their root systems. The larger loss of weight (in relation to the control) noted in cv. Alibi, may suggest that for this cultivar Mn treatment was more stressful than for cv. Nimfa. This conclusion is consistent with the generally accepted assumption that the decrease of tissue mass is an indicator of the intensity of toxic effects in plants (Jaleel et al. 2009). Selenium used at the selected concentration did not affect the appearance of tissues (macroscopic and microscopic observations) or their fresh weight. However, increased weight of both leaves and roots (vs. Mn-only treatment) and reduction of visual effects of $\mathrm{Mn}$, indicate possible Se-induced protection against Mn stress. Thus, our data suggest the possibility of using Se to improve plant resistance to Mn excess.

Yao et al. (2012), who analyzed Mn level in grapes, indicated that depending on the cultivar, either more of this element was retained in the roots or was

treatments (Mn only, $\mathrm{Mn}+\mathrm{Se}$ and Se only). The data are based on the 20 polymorphic loci that represent the genotype specific changes in the methylation events

\begin{tabular}{|c|c|c|c|c|c|c|}
\hline \multirow[t]{2}{*}{ Type of the event } & \multicolumn{3}{|l|}{ Nimfa } & \multicolumn{3}{|l|}{ Alibi } \\
\hline & $\mathrm{C}$ vs $\mathrm{Mn}$ & $\mathrm{C}$ vs $\mathrm{Mn}+\mathrm{Se}$ & $\mathrm{C}$ vs $\mathrm{Se}$ & $\mathrm{C}$ vs $\mathrm{Mn}$ & $\mathrm{C}$ vs $\mathrm{Mn}+\mathrm{Se}$ & $\mathrm{C}$ vs $\mathrm{Se}$ \\
\hline de-Met & 17.50 & 15.91 & 16.25 & 22.37 & 25.00 & 13.07 \\
\hline de novo-Met & 10.63 & 19.32 & 15.00 & 10.53 & 20.83 & 19.89 \\
\hline de-Met-CHG & 7.50 & 6.82 & 6.25 & 11.18 & 13.69 & 3.41 \\
\hline de-Met-CG & 10.00 & 9.09 & 10.00 & 11.18 & 11.31 & 9.66 \\
\hline de novo-Met-CHG & 2.50 & 9.09 & 7.50 & 2.63 & 10.71 & 9.09 \\
\hline de novo-Met-CG & 8.13 & 10.23 & 7.50 & 7.89 & 10.12 & 10.80 \\
\hline
\end{tabular}


distributed to the leaves, even in the resistant plants. It is suggested that the accumulation of greater amounts of stressors (metal ions, toxins) in tissues of susceptible cultivars, as compared with resistant ones, is the main cause of their greater damage (Sieprawska et al. 2017; Kim et al. 2009). Also, in the studies of Millaleo et al. (2010), the correlation between Mn content in selected organs and their destruction occurred even in the same genotype. In our experiments, greater amount of Mn accumulated in the root system than in the leaves of the tested plants may indicate that the roots were more sensitive to Mn stress. However, higher level of $\mathrm{Mn}$ (in both leaves and roots) was found in cv. Nimfa than in cv. Alibi, even though cv. Alibi responded with a greater weight loss. Moreover, the addition of Se (suggested above as a potential protector) further increased the accumulation of $\mathrm{Mn}$. However, the distribution of this element between leaves and roots depended on the cultivar, which is in agreement with the suggestions of Yao et al. (2012). $\mathrm{Mn}$ translocation is also influenced by the chemical form of Se introduced into the culture medium. As shown by Guerrero et al. (2014), the exposure of wheat plants to selenate enhanced Mn root uptake, whereas selenite treatment reduced Mn levels in both roots and shoots, with a particularly strong effect in the shoots. Thus, it seems that it cannot be unequivocally concluded that greater accumulation of $\mathrm{Mn}$ is the only indicator that differentiates sensitivity of the studied cultivars to this stressor. Also, specific properties of the membranes of the investigated cultivars should be taken into account (especially permeability, depending on the content of non-saturated lipids and the presence of ion transporters). Yang et al. (2014) researched specific transporters participating in $\mathrm{Mn}$ translocation. Independently of the uptake by $\mathrm{Mn}$ transporters, Mn can be also absorbed by transporters of other ions of similar value and size.

The change in MDA is considered an indicator of the membrane permeability and fluidity, which depend on the content of non-saturated fatty acids (Ayala et al. 2014). A decrease in lipid unsaturation (recorded as an increase in MDA value) may increase the membrane stiffness and, consequently, modify the activity of membrane transporters and ion channels. The decrease in the nutrient content in the presence of Mn correlated with a decrease in membrane permeability, indirectly shown as an increase in MDA concentration. Significant negative correlations $(\mathrm{r}=-0.802$ to $\mathrm{r}=-0.991, \mathrm{p}<0.05)$ between accumulation of the investigated elements in the leaves and $\mathrm{Mn}$ uptake (both alone and in combination with Se) suggested "blocking the transport" of the other elements under Mn stress. However, in the roots of both cultivars, also positive correlations of $\mathrm{Mn}$ with $\mathrm{Zn}, \mathrm{P}$ and $\mathrm{S}(\mathrm{r}=0.844$ to $\mathrm{r}=0.999 ; \mathrm{p}<0.05)$, and additionally with $\mathrm{Ca}(\mathrm{r}=0.951, \mathrm{p}<0.05)$ for $\mathrm{Mn}+\mathrm{Se}$ variant were shown. Moreover, in the roots of cv. Nimfa, a correlation between $\mathrm{Mn}$ and $\mathrm{Ca}(\mathrm{r}=0.997)$ was noted when Mn was administered alone. The reduced uptake of the studied elements under Mn stress was demonstrated earlier in the leaves of various plant species (Juice et al. 2006; Kleiber 2014). Also, in chloroplasts of wheat seedlings, diminished accumulation of $\mathrm{Zn}$, $\mathrm{Cu}, \mathrm{Fe}, \mathrm{Mg}$ and $\mathrm{Ca}$ was shown under Mn stress (Sieprawska et al. 2017). Altered concentrations of these nutrients may disturb metabolic processes and consequently curb plant growth as manifested in a decrease of fresh weight in the presence of $\mathrm{Mn}$.

Interestingly, the increased uptake of $\mathrm{Ca}$ by the roots of both cultivars under $\mathrm{Mn}+\mathrm{Se}$ treatment, and in cv. Nimfa roots under Mn stress was noted. The importance of $\mathrm{Ca}$ ion as a signal molecule (so-called "secondary messenger"), under stress was described in numerous papers (Thor 2019; Wilkins et al. 2016). As revealed by White et al. (2002), this ion is uptaken from a growth media through plasma membrane channels located in the roots. This may explain why the increase in its amount was evident in the roots. The presence of Se ions can also activate calcium channels partly blocked by Mn, as shown for another stressor (Koselski et al. 2019). Additionally, in Mndamaged roots, extra $\mathrm{Ca}$ uptake stimulated by Se may contribute to "rebuilding" of the tissues. The increase in the concentration of $\mathrm{Ca}$ ions during the initiation of developmental processes was demonstrated in many studies (Hepler 2005; Lamport and Varnai 2013; Thor 2019). This role of Ca may explain the appearance of meristematic centers in the roots of cv. Nimfa treated with Mn (Fig. 4). Ca influx may be also regulated by the generation of ROS during stress reactions (Demidchik et al. 2007). Among $\mathrm{ROS}_{2} \mathrm{O}_{2}$, similarly to $\mathrm{Ca}$, is the molecule recognized as an important element of cell signaling (Demidchik et al. 2007), independently of its ability to oxidize biomolecules and disrupt their functioning. Thus, a significant increase in $\mathrm{H}_{2} \mathrm{O}_{2}$ concentration in the presence of $\mathrm{Mn}$, especially visible in the roots (as compared with control), 
may indicate both greater intensity of stress in these organs, but also, as in the case of $\mathrm{Ca}$, its involvement in "chemical signaling process" leading to limited tissue destruction (roots).

Microscopic observations and analysis of DNA methylation

Special function of the roots was indicated by the fact that microscopic observations of the leaf structures showed smaller damage of these organs in the presence of Mn than the roots. Main changes in the leaf tissues involved chloroplast formation and the amount and distribution of starch in these organelles. The quantitative changes and redistribution of starch in chloroplasts were found under various environmental stressors (Filek et al. 2010). Our earlier studies also showed a genotype resistance-dependent increase in the accumulation of this polysaccharide (Sieprawska et al. 2017). Small differences regarding the chloroplasts modification of the investigated plants treated with $\mathrm{Mn}$, were mainly registered as changes in distribution of these organelles in the cells. Starch distribution within the chloroplasts (Fig. 2) correlated with the increase in its concentration, registered biochemically (Table 2). It may indicate a comparable susceptibility of both cultivars to Mn. However, in cv. Alibi we also found partly damaged leaves with changes in the chloroplasts typical of less tolerant plants. The stimulation of protective mechanisms under Mn stress was evidenced by an almost twofold increase in the concentration of soluble sugars in both cultivars. These molecules are regarded as osmoprotective agents, the accumulation of which may reduce negative effects of many stressors (Rosa et al. 2009). Relatively high level of soluble sugars accompanied by reduced starch content and smaller microscopically visible damage in the leaves may confirm the involvement of $\mathrm{Se}$ in the protective reactions against $\mathrm{Mn}$ stress, as suggested based on the experiments described above.

Larger anatomical differences between the examined cultivars exposed to Mn were observed in the roots. In cv. Alibi, changes in the shape of meristematic cells were noted, and a reduction in the number and extent of structural damage of the cap cells, as well as the appearance, in the area between the meristem and the differentiation zone, of additional (compared to the control) groups of oval cells, larger than the surrounding cells (Fig. 4B'). Their presence may indicate a potential change in the direction of cell differentiation in this area of the root. Moreover, in the elongation zone, cells were often irregular in shape, some without visible nuclei. Such modifications may suggest that $\mathrm{Mn}$ induced faster apoptosis of the cap cells and impaired differentiation of root tissues. In cv. Nimfa roots treated with $\mathrm{Mn}$ we found a decrease in the number of cap cells in comparison with control (Fig. 4C). A characteristic change, observed only in this cultivar, was the presence of a group of small cells, with large nuclei and condensed chromatin, visible at the border of the meristem and differentiation zone (Fig. 4C'). Presumably, these are procortex cells that differentiate into a new root apex. Creation of inappropriate root branching as a consequence of damage to the apical meristem were found by Clarkson (1969) and Llugany et al. (2003). We suggest that the formation of the new root apexes could be an element of plant defence mechanisms allowing for plant regeneration even after death of the primary roots. It may be related to the increase in $\mathrm{Ca}$ content in these cultivars observed in the presence of $\mathrm{Mn}$, as suggested above. Independently of the stress reactions induced by $\mathrm{Mn}$, the protective role of $\mathrm{Se}$ was also revealed in anatomical observations of the roots, as a reduction of changes caused by the presence of Mn.

The anatomical modifications induced by $\mathrm{Mn}$ in the leaves of the studied cultivars, mainly in the form of starch accumulation in plastids, were not accompanied by changes in DNA methylation determined based on the global level of 5-metC detected with immunocytochemical method and the analysis of methylation status of CCGG sequences with MSAP method.

Contrary to that, our analysis of wheat roots indicated that the global 5-metC level varied in different root zones and tissues. Kumpf and Nowack (2015) reported a very low level of DNA methylation in dividing, undifferentiated meristematic cells and short-lived cap cells, which soon enter the path of apoptosis. However, we showed for the first time a progressive increase in DNA methylation from dividing meristematic cells to differentiating and elongating cells of the vascular cylinder and cortex, as measured by the global 5-metC level. The role of DNA methylation in the processes of plant tissue differentiation is well known (Brown 1989; Ikeuchi et al. 
2015). Elevated levels of 5-metC in the meristem and cap cells in the presence of Mn likely reflect the process of their apoptosis. The higher 5-metC content in cv. Alibi was observed only in a few cells of the cap and meristem, while in cv. Nimfa it was found in all visible cell nuclei. We may then conclude that in this cultivar Mn absorption could lead to cell apoptosis and death of the main growth apex. The phenomenon of DNA methylation during apoptosis was described in Danio rerio cells subjected to malnutrition stress (Fan et al. 2020).

Moreover, microscopic observations indicated that in both cultivars, cells of the differentiation zone had the potential ability to change their differentiation pattern in the presence of $\mathrm{Mn}$, probably towards formation of an additional growth apex. This process seemed to be faster in the cultivar Nimfa, in which Mn stress strongly damaged meristematic root cells. Mn uptake resulted in faster apoptosis of the cap cells and impaired differentiation of root tissues. These processes were accompanied by changes in DNA methylation. Our study is the first to report a progressive increase in DNA methylation from dividing meristematic cells to elongating cells of the axial cylinder and cortex, as measured by global 5-metC level. The increase in 5-metC methylation signals after the treatment with Mn may result from the activation of pathways that counteract the transposon movement. A characteristic feature observed in both cultivars under Mn was the presence of groups of distinct cells in the meristem-differentiation zone. In cv. Alibi they were larger cells (Fig. 4B') with slightly reduced 5-metC level (Figs. 5IIB, 6A). In cv. Nimfa they were a group of small cells with highly condensed DNA (Fig. 4C') and increased level of DNA methylation (Figs. 5IIIB, 6B). It can be assumed that these are cells whose differentiation was altered. Mn induced process of changing the direction of differentiation was likely accompanied by changes in DNA methylation. In cv. Nimfa, with the death of the main grows apex, these cells are probably differentiating into new root apexes. The formation of a new root apex could serve as a defense mechanism for the plant in the event of the main root apex dieback.

Contrary to the increase in cytosine methylation reflected by global level of 5-metC in the root nuclei, our MSAP analysis showed the predominance of demethylation events at CCGG sites after $\mathrm{Mn}$ and $\mathrm{Mn}+\mathrm{Se}$ treatments in the roots of both cultivars.
These discrepancies may be explained in two ways. The MSAP analysis was based on the homogenized material from the entire root system, thus the results were averaged across all root zones and all tissue types, whereas the quantification of global level of 5-metC was directed to specific zones and tissues. The second possible explanation is related to the resolution of the analysis and the type of sequence context where the methylated cytosine may be present. Here, the MSAP method gives much higher resolution than in situ hybridization, as it allows us to detect the methylation status of sequences located in very close proximity to each other. On the other hand, the MSAP method, which utilizes HpaII and MspI restriction enzymes, is directed for the analysis of CCGG sequences only and in situ hybridization allows for detecting also other sequences with methylated cytosine residues. This kind of explanation seems even more plausible, as it indicates that the stress related to high doses of Mn may preferentially induce de novo methylation of cytosines in other sequence contexts, for example in asymmetric $\mathrm{CHH}$ sites (where $\mathrm{H}$ indicates any nucleotide except for G). In many species, the asymmetric $\mathrm{CHH}$ sites are often present in heterochromatin and within or nearby transposons and retrotransposons, which need to be silenced to prevent the instability of the genome (Zhang et al. 2018). We may therefore hypothesize that the increase in 5-metC methylation signals after the treatment with Mn may result from the activation of pathways that counteract the transposon movement. At the same time our in situ hybridization analysis showed that the addition of Se to the medium with Mn resulted in similar methylation levels as found in control. This may support the hypothesis of the protective role of Se ions in wheat subjected to high concentration of $\mathrm{Mn}$, as in their presence the activation of the mechanisms of genome stability protection may not be necessary.

Following up on this hypothesis, we may assume that at least some CCGG sequences targeted by the MSAP method may be located in the gene coding regions. It was showed that methylated CG clusters are present in the gene body of many constitutively expressed genes (Tran et al. 2005), and that methylation of CHG sequences can also correlate with gene expression activation (Bewick and Schmitz 2017). The demethylation events detected in our MSAP analysis after $\mathrm{Mn}$ and $\mathrm{Mn}+\mathrm{Se}$ treatments may reflect the necessity of differential regulation of gene expression 
at particular loci in the presence of these ions. It is also known, however, that the link between methylation level of CG and CHG sites and the level of gene expression is highly gene-specific (Bewick and Schmitz 2017), which mitigates the straightforward interpretation of such results. Nonetheless, the complex changes in DNA methylation patterns that emerge from our study encourage a much deeper analysis based on DNA bisulfide sequencing in order to identify specific genes that may be regulated by differential methylation status in response to $\mathrm{Mn}$ and Se ions. This may support the hypothesis of protective role of Se ions in wheat subjected to high concentration of $\mathrm{Mn}$, as in their presence the activation of the mechanisms of genome stability protection may not be necessary.

\section{Conclusions}

The presented research demonstrates that the root system of wheat seedlings is where most plant reactions to toxic doses of Mn take place. The responses were indicated as a considerable reduction of root weight and disturbances of their macroscopic and microscopic structure, especially within the apical parts. Se ions may have a protective effect on plants also under Mn stress. The mechanism of action of Se ions was not related to a direct blockage of Mn influx to the cells. Se-stimulated uptake of $\mathrm{Ca}$ ions seems to be an important step in this process, enabling regeneration of root tissues.

Microscopic observations indicated the potential ability of the meristem zone of roots to modify their differentiation pattern under Mn stress, more significantly in the case of strong damage to the meristematic and cap cells. These changes were related to a progressive increase in global DNA methylation from dividing meristematic cells to elongating cells of the axial vascular cylinder and cortex, what was indicated for the first time in our studies. Based on the DNA methylation profiles detected by MSAP, we hypothesize that different types of methylation sites may undergo different changes in the methylation pattern. We presume that asymmetric $\mathrm{CHH}$ sequences may come under preferential methylation in the presence of high doses of Mn, which is blocked or slowed down by Se addition, whereas other types of sequences, i.e., CGs and CHGs may undergo preferential demethylation both under $\mathrm{Mn}$ and $\mathrm{Mn}+\mathrm{Se}$ treatment.
In summary, it may be assumed that Mn ions accumulate mainly in the cells of the "main" root apex. After exceeding its maximum concentration, the meristematic cells die (apoptosis), but new root buds differentiate rapidly and compensate for the loss of the dead cells. Thus, the plant can still take up Mn that is transported to the leaves. This may explain why in cv. Nimfa roots, where we observed the formation of new meristematic centers, the toxic processes were not as pronounced as in $\mathrm{cv}$. Alibi, despite greater Mn uptake. Another explanation may be the possibility of Mn storage in degenerated fragments of roots. Such effects were not seen in cv. Alibi, which absorbed less Mn but transported it to the leaves.

Author contributions Conceptualization, A.S. and M.S.; methodology, software and validation, A.S., M.S., E. B-K, K.N., A.J. and A.T.; formal analysis and writing-original draft preparation A. S., M.S., E. B-K, A. J. and M.F.; visualization, M.S., E. B-K. and A.J, supervision, M.F. All authors have read and agreed to the published version of the manuscript.

Data availability Not applicable.

\section{Declarations}

Conflicts of interest The author declares no conflict of interest.

Institutional review board statement Not applicable.

Informed consent statement Not applicable.

Open Access This article is licensed under a Creative Commons Attribution 4.0 International License, which permits use, sharing, adaptation, distribution and reproduction in any medium or format, as long as you give appropriate credit to the original author(s) and the source, provide a link to the Creative Commons licence, and indicate if changes were made. The images or other third party material in this article are included in the article's Creative Commons licence, unless indicated otherwise in a credit line to the material. If material is not included in the article's Creative Commons licence and your intended use is not permitted by statutory regulation or exceeds the permitted use, you will need to obtain permission directly from the copyright holder. To view a copy of this licence, visit http://creativecommons.org/licenses/by/4.0/.

\section{References}

Andresen E, Peiter E, Küpper H (2018) Trace metal metabolism in plants. J Exp Bot 69:909-954. https://doi.org/10. 1093/jxb/erx465 
Ayala A, Munoz MF, Arguelles S (2014) Lipid peroxidation: production, metabolism, and signaling mechanisms of malondialdehyde and 4-hydroxy-2-nonenal. Oxid Med Cell Longev 360438. https://doi.org/10.1155/2014/360438

Bednarek PT, Orłowska R, Niedziela AA (2017) Relative quantitative methylation-sensitive amplified polymorphism (MSAP) method for the analysis of abiotic stress. BMC Plant Biol 17(1):1-13. https://doi.org/10.1186/ s12870-017-1028-0

Bewick AJ, Schmitz RJ (2017) Gene body DNA methylation in plants. Curr Opin Plant Biol 36:103-110. https://doi.org/ 10.1016/j.pbi.2016.12.007

Broadley M, Brown P, Cakmak I, Rengel Z, Zhao F (2012) Function of nutrients: Micronutrients. Academic Press Inc, San Diego, pp 191-248

Brown PTH (1989) DNA methylation in plants and its role in tissue culture. Genome 31(2):717-729. https://doi.org/ 10.1139/g89-130

Cakmak I, Yazici AM (2010) Magnesium: a forgotten element in crop production. Better Crops 94(2):23-25

Chen X, Zhou DX (2013) Rice epigenomics and epigenetics: challenges and opportunities. Curr Opin Plant Biol 16(2):164-169. https://doi.org/10.1016/j.pbi.2013.03. 004

Chen Z, Yan W, Sun L, Tian J, Liao H (2016) Proteomic analysis reveals growth inhibition of soybean roots by manganese toxicity is associated with alteration of cell wall structure and lignification. J Proteomics 143:151-160. https://doi.org/10.1016/j.jprot.2016.03.037

Clarkson DT (1969) Metabolic aspects of aluminium toxicity and some possible mechanisms for resistance. In: Rorison IH (ed) British Ecological Symposium No. 9. Blackwell Scientific Publications, Oxford and Edinburgh, pp 381-397

Demidchik V, Shabala SN, Davies JM (2007) Spatial variation in $\mathrm{H}_{2} \mathrm{O}_{2}$ response of Arabidopsis thaliana root epidermal $\mathrm{Ca}^{2+}$ flux and plasma membrane $\mathrm{Ca}^{2+}$ channels. Plant J 49(3):377-386. https://doi.org/10.1111/j.1365-313X. 2006.02971.x

Dhindsa RS, Plumb-Dhindsa P, Thorpe TA (1981) Leaf senescence: correlated with increased levels of membrane permeability and lipid peroxidation, and decreased levels of superoxide dismutase and catalase. J Exp Bot 32(1):93101. https://doi.org/10.1093/jxb/32.1.93

Doyle JJ, Doyle JL (1987) A rapid DNA isolation procedure for small quantities of fresh leaf tissue. Phytochemical Bulletin 19:11-15

Fan X, Hou T, Guan Y, Li X, Zhang S, Wang Z (2020) Genomic responses of DNA methylation and transcript profiles in zebrafish cells upon nutrient deprivation stress. Sci Total Environ 722:137980. https://doi.org/10.1016/j. scitotenv.2020.137980

Fecht-Christoffers MM, Braun HP, Lemaitre-Guillier C, VanDorsselaer A, Horst WJ (2003) Effect of manganese toxicity on the proteome of the leaf apoplast in cowpea. Plant Physiol 133(4):1935-1946. https://doi.org/10.1104/pp. 103.029215

Filek M, Keskinen R, Hartikainen H, Szarejko I, Janiak A, Miszalski Z, Golda A (2008) The protective role of selenium in rape seedlings subjected to cadmium stress. J
Plant Physiol 165:833-844. https://doi.org/10.1016/j. jplph.2007.06.006

Filek M, Kościelniak J, Łabanowska M, Bednarska E, Bidzińska E (2010) Selenium-induced protection of photosynthesis activity in rape (Brassica napus) seedlings subjected to cadmium stress. Fluorescence and EPR Measurements Photosynth Res 105:27-37. https://doi.org/ 10.1007/s11120-010-9551-y

Führs H, Kopka J, Braun HP, Horst WJ (2009) Metabolomic and Proteomic Analysis of Manganese Sensitivity and Tolerance in the Tropical Legume Cowpea (Vigna unguiculata L.). The Proceedings of the International Plant Nutrition Colloquium XVI pp 1068

Führs H, Specht A, Erban A, Kopka J, Horst WJ (2012) Functional associations between the metabolome and manganese tolerance in Vigna unguiculata. J Exp Bot 63(1):329340. https://doi.org/10.1093/jxb/err276

Gayacharan Joel AJ (2013) Epigenetic responses to drought stress in rice (Oryza sativa L.). Physiol Mol Biol Plants 19(3):379-387. https://doi.org/10.1007/ s12298-013-0176-4

Grafi G, Florentin A, Ransbotyn V, Morgenstern Y (2011) The stem cell state in plant development and in response to stress. Front Plant Sci 2:53. https://doi.org/10.3389/fpls. 2011.00053

Greco M, Chiappetta A, Bruno L, Bitonti MB (2012) In Posidonia oceanica cadmium induces changes in DNA methylation and chromatin patterning. J Exp Bot 63(2):695709. https://doi.org/10.1093/jxb/err313

Guerrero B, Llugany M, Palacios O, Valiente M (2014) Dual effects of different selenium species on wheat. Plant Physiol Biochem 83:300-307. https://doi.org/10.1016/j.plaphy. 2014.08.009

Gupta M, Gupta S (2017) An overview of selenium uptake, metabolism, and toxicity in plants. Front Plant Sci 7:2074. https://doi.org/10.3389/fpls.2016.02074

Guzy-Wróbelska J, Filek M, Kaliciak A, Szarejko I, Macháčková I, Krekule J, Barciszewska M (2013) Vernalization and photoperiod-related changes in the DNA methylation state in winter and spring rapeseed. Acta Physiol Plant 35:817-827. https://doi.org/10.1007/ s11738-012-1126-4

Gzyl-Malcher B, Rudolphi-Skórska E, Sieprawska A, Filek M (2019) Manganese protects wheat from the mycotoxin zearalenone and its derivatives. Sci Rep 9(1):1-12. https:// doi.org/10.1038/s41598-019-50664-5

Hafeez B, Khanif YM, Saleem M (2013) Role of zinc in plant nutrition-a review. J Exp Agric Int 3(2):374-391. https:// doi.org/10.9734/AJEA/2013/2746

Hepler PK (2005) Calcium: a central regulator of plant growth and development. Plant Cell 17(8):2142-2155. https://doi. org/10.1105/tpc.105.032508

Huang H, Zhao Y, Xu Z, Zhang W, Jiang K (2019) Physiological responses of Broussonetia papyrifera to manganese stress, a candidate plant for phytoremediation. Ecotoxicol Environ Saf 181:18-25. https://doi.org/10.1016/j.ecoenv. 2019.05.063

Huber SC, Israel DW (1982) Biochemical basis for partitioning of photosynthetically fixed carbon between starch and sucrose in soybean (Glycine max Merr.) leaves. Plant 
physiol 69(3):691-696. https://doi.org/10.1104/pp.69.3. 691

Ikeuchi M, Iwase A, Sugimoto K (2015) Control of plant cell differentiation by histone modification and DNA methylation. Curr Opin Plant Biol 28:60-67. https://doi.org/10. 1016/j.pbi.2015.09.004

Jaleel CA, Manivannan P, Wahid A, Farooq M, Al-Juburi HJ, Somasundaram R, Panneerselvam R (2009) Drought stress in plants: A review on morphological characteristics and pigments composition. Int J Agric Biol 11:100-105

Janeczko A, Biesaga-Kościelniak J, Oklešt'ková J, Filek M, Dziurka M, Szarek-Łukaszewska G, Kościelniak J (2010) Role of 24-epibrassinolide in wheat production: physiological effects and uptake. J Agron Crop Sci 196(4):311-321. https://doi.org/10.1111/j.1439-037X. 2009.00413.x

Juice SM, Fahey TJ, Siccama TG, Driscoll CT, Denny EG, Eagar C, Cleavitt NL, Minocha R, Richardson AD (2006) Response of sugar maple to calcium addition to northern hardwood forest. Ecology 87:1267-1280. https://doi.org/10.1890/0012-9658(2006)87[1267: ROSMTC]2.0.CO;2

Karan R, DeLeon T, Biradar H, Subudhi PK (2012) Salt stress induced variation in DNA methylation pattern and its influence on gene expression in contrasting rice genotypes. PLoS ONE 7(6):e40203. https://doi.org/10. 1371/journal.pone.0040203

Kim YY, Choi H, Segami S, Cho HT, Martinoia E, Maeshima M, Lee Y (2009) AtHMA1contributes to the detoxification of excess $\mathrm{Zn}(\mathrm{II})$ in Arabidopsis. Plant J 58:737753. https://doi.org/10.1111/j.1365-313X.2009.03818.x

Kleiber T (2014) Effect of Manganese Nutrition on Content of Nutrient and Yield of Lettuce (Lactuca Sativa L.) in Hydroponic. Ecol Chem Eng 21(3):529-537. https://doi. org/10.2478/eces-2014-0039

Kleiber T, Krzesiński W, Przygocka-Cyna K, Spiżewski T (2018) Alleviation effect of selenium on manganese stress of plants. Ecol Chem Eng 25(1):143-152. https:// doi.org/10.1515/eces-2018-0010

Koselski M, Dziubińska H, Trębacz K, Sieprawska A, Filek M (2019) The Role of SV Ion Channels Under the Stress of Mycotoxins Induced in Wheat CellsProtective Action of Selenium Ions. J Plant Growth Regul 38(4):1255-1259. https://doi.org/10.1007/ s00344-019-09930-z

Kozłowska M, Niedojadło K, Brzostek M, Bednarska-Kozakiewicz E (2016) Epigenetic marks in the Hyacinthus orientalis L. mature pollen grain and during in vitro pollen tube growth. Plant Reprod 29(3):251-263. https://doi.org/ 10.1007/s00497-016-0289-3

Kumpf RP, Nowack MK (2015) The root cap: a short story of life and death. J Exp Bot 66(19):5651-5662. https://doi. org/10.1093/jxb/erv295

Lamport DT, Varnai P (2013) Periplasmic arabinogalactan glycoproteins act as a calcium capacitor that regulates plant growth and development. New Phytol 197:58-64. https:// doi.org/10.1111/nph.12005

Li Q, Chen LS, Jiang HX, Tang N, Yang LT, Lin ZH, Li Y, Yang GH (2010) Effects of manganese-excess on $\mathrm{CO}_{2}$ assimilation, ribulose-1,5-bisphosphate carboxylase/ oxygenase, carbohydrates and photosynthetic electron transport of leaves, and antioxidant systems of leaves and roots in Citrus grandis seedlings. BMC Plant Biol 10:42. https://doi.org/10.1186/1471-2229-10-42

Liang T, Ding H, Wang G, Kang J, Pang H, Lv J (2016) Sulfur decreases cadmium translocation and enhances cadmium tolerance by promoting sulfur assimilation and glutathione metabolism in Brassica chinensis L. Ecotoxicol Environ Saf 124:129-137. https://doi.org/10.1016/j.ecoenv.2015. 10.011

Llugany M, Lombini A, Poschenrieder C, Dinelli E, Barceló J (2003) Different mechanisms account for enhanced copper resistance in Silene armeria ecotypes from mine spoil and serpentine sites. Plant Soil 251(1):55-63. https://doi. org/10.1023/A:1022990525632

Maathuis FJ, Diatloff E (2013) Roles and functions of plant mineral nutrients. Springer, Berlin/Heidelberg, Germany, pp 1-21

Malhotra H, Sharma S, Pandey R (2018) Phosphorus nutrition: Plant growth in response to deficiency and excess. Springer, Singapore pp 171-190

Mann MB, Smith HO (1977) Specificity of HpaII and HaeIII DNA methylases. Nucleic Acids Res 4(12):4211-4221. https://doi.org/10.1093/nar/4.12.4211

Mechora Š (2019) Selenium as a protective agent against pests: a review. Plants 8(8):262. https://doi.org/10.3390/ plants 8080262

Millaleo R, Reyes-Díaz M, Alberdi M, Ivanov AG, Krol M, Hüner NPA (2013) Excess manganese differentially inhibits photosystem I versus II in Arabidopsis thaliana. J Exp Bot 64(1):343-354. https://doi.org/10.1093/jxb/ ers339

Millaleo R, Reyes-Díaz M, Ivanov AG, Mora ML, Alberdi M (2010) Manganese as essential and toxic element for plants: Transport, accumulation and resistance mechanisms. J Soil Sci Plant Nutr 10:470-481. https://doi.org/ 10.4067/S0718-95162010000200008

Mishra S, Srivastava S, Tripathi RD, Govindarajan R, Kuriakose SV, Prasad MNV (2006) Phytochelatin synthesis and response of antioxidants during cadmium stress in Bacopa monnieri L. Plant Physiol Biochem 44(1):25-37. https:// doi.org/10.1016/j.plaphy.2006.01.007

Niedojadło K, Hyjek M, Bednarska-Kozakiewicz E (2015) Spatial and temporal localization of homogalacturonans in Hyacinthus orientalis L. ovule cells before and after fertilization. Plant Cell Rep 34(1):97-109. https://doi.org/10. 1007/s00299-014-1690-8

Nita M, Grzybowski A (2016) The role of the reactive oxygen species and oxidative stress in the pathomechanism of the age-related ocular diseases and other pathologies of the anterior and posterior eye segments in adults. Oxid Med Cell Longev 3164734. https://doi.org/10.1155/2016/ 3164734

Rahman A, Hossain MS, Mahmud JA, Nahar K, Hasanuzzaman M, Fujita M (2016) Manganese-induced salt stress tolerance in rice seedlings: regulation of ion homeostasis, antioxidant defense and glyoxalase systems. Physiol Mol Biol Plants 22(3):291-306. https://doi.org/10.1007/ s12298-016-0371-1

Rajpoot R, Srivastava RK, Pandey RA, P, Dubey RS, (2021) Manganese-induced oxidative stress, ultrastructural changes, and proteomics studies in rice plants. 
Protoplasma 258(2):319-335. https://doi.org/10.1007/ s00709-020-01575-0

Razaq M, Zhang P, Shen HL (2017) Influence of nitrogen and phosphorous on the growth and root morphology of Acer mono. PLoS ONE 12(2):e0171321. https://doi.org/10. 1371/journal.pone.0171321

Reyna-Lopez GE, Simpson J, Ruiz-Herrera J (1997) Differences in DNA methylation patterns are detectable during the dimorphic transition of fungi by amplification of restriction polymorphisms. Mol Gen Genet 253(6):703710. https://doi.org/10.1007/s004380050374

Röllin HB, Nogueira CMCA (2011) Manganese: environmental pollution and health effects. 229-242. https://doi.org/ 10.1016/B978-0-444-52272-6.00540-7

Rosa M, Prado C, Podazza G, Interdonato R, González JA, Hilal M, Prado FE (2009) Soluble sugars: Metabolism, sensing and abiotic stress: A complex network in the life of plants. Plant Signal Behav 4(5):388-393. https://doi. org/10.4161/psb.4.5.8294

Rout GR, Sahoo S (2011) Role of iron in plant growth and metabolism. J Agric Sci 3:1-24. https://doi.org/10.7831/ ras.3.1

Sasaki A, Yamaji N, Yokosho K, Ma JF (2012) Nramp5 is a major transporter responsible for manganese and cadmium uptake in rice. Plant Cell 24:2155-2167. https://doi. org/10.1105/tpc.112.096925

Scheers N (2013) Regulatory effects of $\mathrm{Cu}, \mathrm{Zn}$, and Ca on Fe absorption: the intricate play between nutrient transporters. Nutrients 5(3):957-970. https://doi.org/10.3390/ nu5030957

Schmidt SB, Husted S (2019) The biochemical properties of manganese in plants. Plants 8(10):381. https://doi.org/10. 3390/plants 8100381

Sebastian A, Prasad MNV (2015) Iron- and manganeseassisted cadmium tolerance in Oryza sativa L.: Lowering of rhizotoxicity next to functional photosynthesis. Planta 241:1519-1528. https://doi.org/10.1007/ s00425-015-2276-6

Selvaraj K (2018) Effect of nickel chloride on the growth and biochemical characteristics of phaseolus mungol. JOJ Sciences 1(2):18-23

Sergiev I, Alexieva V, Karanov E (1997) Effect of spermine, atrazine and combination between them on some endogenous protective systems and stress markers in plants. Compt Rend Acad Bulg Sc 51:121-124

Shan X, Wang X, Yang G, Wu Y, Su S, Li S, Liu H, Yuan Y (2013) Analysis of the DNA methylation of maize (Zea mays L.) in response to cold stress based on methylationsensitive amplified polymorphisms. J Plant Biol 56:32-38. https://doi.org/10.1007/s12374-012-0251-3

Sharma A, Shankhdhar D, Shankhdhar SC (2017) The role of calcium in plant signal transduction under macronutrient deficiency stress. Academic Press, London, pp 181-196

Sharma SS, Dietz KJ (2009) The relationship between metal toxicity and cellular redox imbalance. Trends Plant Sci 14(1):43-50. https://doi.org/10.1016/j.tplants.2008.10.007

Shi Q, Zhu Z (2008) Effects of exogenous salicylic acid on manganese toxicity, element contents and antioxidative system in cucumber. Environ Exp Bot 63(1-3):317-326. https://doi.org/10.1016/j.envexpbot.2007.11.003
Sieprawska A, Filek M, Tobiasz A, Bednarska-Kozakiewicz E, Walas S, Dudek-Adamska D, Grygo-Szymanko E (2017) Response of chloroplasts of tolerant and sensitive wheat genotypes to manganese excess: Structural and biochemical properties. Acta Physiol Plant 39:6. https://doi.org/10. 1007/s11738-016-2302-8

Sieprawska A, Kornaś A, Filek M (2015) Involvement of selenium in protective mechanisms of plants under environmental stress conditions-review. Acta Biol Crac Ser Bot 57(1):9-20. https://doi.org/10.1515/abcsb-2015-0014

Tan MP (2010) Analysis of DNA methylation of maize in response to osmotic and salt stress based on methylationsensitive amplified polymorphism. Plant Physiol Biochem 48(1):21-26. https://doi.org/10.1016/j.plaphy.2009.10.005

Thor K (2019) Calcium-Nutrient and messenger. Front Plant Sci 10:440. https://doi.org/10.3389/fpls.2019.00440

Tobiasz A, Walas S, Filek M, Mrowiec H, Samsel K, Sieprawska A, Hartikainen H (2014) Evaluation of selenium effect on micro-and macroelements distribution to different wheat tissues during principal plant development stages. Biol Plant 58:370-374. https://doi.org/10.1007/ s10535-014-0407-8

Tran RK, Henikoff JG, Zilberman D, Ditt RF, Jacobsen SE, Henikoff S (2005) DNA methylation profiling identifies CG methylation clusters in Arabidopsis genes. Curr Biol 15(2):154-159. https://doi.org/10.1016/j.cub.2005.01.008

Wang M, Zheng Q, Shen Q, Guo S (2013) The critical role of potassium in plant stress response. Int $\mathrm{J}$ Mol Sci 1-4(4):7370-7390. https://doi.org/10.3390/ijms 14047370

White PJ, Bowen HC, Demidchik V, Nichols C, Davies JM (2002) Genes for calcium-permeable channels in the plasma membrane of plant root cells. BBA-Biomembranes 1564(2):299-309. https://doi.org/10.1016/S00052736(02)00509-6

Wilkins KA, Matthus E, Swarbreck SM, Davies JM (2016) Calcium-mediated abiotic stress signaling in roots. Front Plant Sci 7:1296. https://doi.org/10.3389/fpls.2016.01296

Yang M, Zhang YY, Zhang L, Hu J, Zhang X, Lu K, Dong H, Wang D, Zhao FJ, Huang CF, Lian X (2014) OsNRAMP5 contributes to manganese translocation and distribution in rice shoots. J Ex Bot 65:4849-4861. https://doi.org/10. 1093/jxb/eru259

Yao Y, Xu G, Mou D, Wang J, Ma J (2012) Subcellular Mn compartation, anatomic and biochemical changes of two grape varieties in response to excess manganese. Chemosphere 89(2):150-157. https://doi.org/10.1016/j.chemo sphere.2012.05.030

Zhang H, Lang Z, Zhu JK (2018) Dynamics and function of DNA methylation in plants. Nat Rev Mol Cell Biol 19(8):489-506. https://doi.org/10.1038/ s41580-018-0016-Z

Publisher's note Springer Nature remains neutral with regard to jurisdictional claims in published maps and institutional affiliations. 